Columbia Law School

Scholarship Archive

\title{
Understanding the Plaintiff's Attorney: The Implications of Economic Theory for Private Enforcement of Law Through Class and Derivative Actions
}

John C. Coffee Jr.

Columbia Law School, jcoffee@law.columbia.edu

Follow this and additional works at: https://scholarship.law.columbia.edu/faculty_scholarship

Part of the Environmental Law Commons, Law and Economics Commons, and the Torts Commons

\section{Recommended Citation}

John C. Coffee Jr., Understanding the Plaintiff's Attorney: The Implications of Economic Theory for Private Enforcement of Law Through Class and Derivative Actions, 86 CoLUM. L. REV. 669 (1986).

Available at: https://scholarship.law.columbia.edu/faculty_scholarship/26

This Article is brought to you for free and open access by the Faculty Publications at Scholarship Archive. It has been accepted for inclusion in Faculty Scholarship by an authorized administrator of Scholarship Archive. For more information, please contact scholarshiparchive@law.columbia.edu. 


\title{
COLUMBIA LAW REVIEW
}

VOL. 86

MAY 1986

NO. 4

UNDERSTANDING THE PLAINTIFF'S ATTORNEY: THE IMPLICATIONS OF ECONOMIC THEORY FOR PRIVATE ENFORCEMENT OF LAW THROUGH CLASS AND DERIVATIVE ACTIONS

\author{
John C. Coffee, Jr.*
}

\section{INTRODUCTION}

Probably to a unique degree, American law relies upon private litigants to enforce substantive provisions of law that in other legal systems are left largely to the discretion of public enforcement agencies. This system of enforcement through "private attorneys general" is most closely associated with the federal antitrust and securities laws and the common law's derivative action, but similar institutional arrangements have developed recently in the environmental, "mass tort," and employment discrimination fields." The key legal rules that make

* Adolf A. Berle Professor of Law, Columbia University.

1. Because this Article examines the plaintiff's attorney as an independent monitoring force, a brief review of the development of private enforcement is in order. The term "private attorney general" was coined by Judge Jerome Frank to refer to one who brought an action to "vindicate the public interest." Associated Indus., Inc. v. Ickes, 134 F.2d 694, 704, 705 (2d Cir.), vacated as moot, 320 U.S. 707 (1943). The professional plaintiff's attorney, however, appeared at least several decades earlier. The plaintiff's attorney was probably first able to function as a "bounty-hunter"- that is, as a profit-motivated entrepreneur who is relatively unconstrained by the interests of any specific client-in the context of derivative litigation. For a colorful account of Clarence Venner, the pioneer of the "strike suit" in the first decade of this century, see J. Livingston, The American Stockholder 55 (1958) (describing Venner as "a legal Robin Hood," but also noting that this "policeman . . . would sell his nightstick-at a price"). For a representative case, see Venner v. Great N. Ry., 209 U.S. 24 (1908). By the 1930s, the expression "strike suit" was already understood to mean a derivative action whose nuisance value gave it a settlement value independent of its merits. See Note, Extortionate Corporate Litigation: The Strike Suit, 34 Colum. L. Rev. 1308 (1934). The debate over the utility of derivative litigation continues today and shows no signs of abating. See American Law Institute, Principles of Corporate Governance: Analysis and Recommendations 3-I4 (Discussion Draft No. 1 1985).

The primary locus of "entrepreneurial" private enforcement, however, has shifted away from derivative litigation. During the 1950 s and 1960 s, skilled plaintiff's attorneys, such as Harold Kohn and David Berger, perfected the antitrust class action. See Bruck, Harold Kohn Against the World, Am. Law., Jan. 1982, at 28. Once again, critics were quick to describe this development as leading to "legalized blackmail." See Handler, The Shift from Substantive to Procedural Innovations in Antitrust Suits-The Twenty-Third Annual Antitrust Review, 71 Colum. L. Rev. 1, 9 (1971). During the $1970 \mathrm{~s}$, the recognition of implied causes of action, particularly under Rule $10 \mathrm{~b}-5$, resulted in a sudden increase in securities class actions. For a review of the state-of-the-art in this field, see Berton, Auditors' Nemesis: Class-Action Lawyer Beats the CPA Firms 
the private attorney general a reality in American law today, however, are not substantive but procedural-namely, those rules that establish the fee arrangements under which these plaintiff's attorneys are compensated. ${ }^{2}$ Inevitably, these rules create an incentive structure that either encourages or chills private enforcement of law.

Over the last decade, as criticism of private enforcement has mounted ${ }^{3}$ and the caseload pressure on the federal judiciary has inten-

At Their Own Game, Wall St. J., Dec. 4, 1985, at 1, col. 1 (describing Melvyn Weiss, probably the most successful plaintiff's attorney in the securities class action field).

Most recently, there has been a similar explosion of activity in the "mass tort" field, particularly in toxic products class actions that raise complex issues of causation and scientific proof. Considerable publicity has attended litigation concerning Agent Orange, the Dalkon Shield, asbestos, Bendectin, Rely tampons, and, most recently, the Bhopal, India tragedy. For profiles of the "new breed" of plaintiff's attorneys who litigate these actions, see Wagner, The New Elite Plaintiffs' Bar, A.B.A.J., Feb. 1, 1986, at 44. A key characteristic of these attorneys appears to be their ability to make substantial cash investments in an action. For example, in the Agent Orange case, five plaintiff's attorneys each contributed a minimum of $\$ 250,000$ to a common expense fund, and the plaintiff's management committee spent almost $\$ 2,000,000$ in expenses over a ninemonth period in preparation for trial. Id. Investments and expenditures at such a level suggest the utility of an economic analysis.

2. Four such legal rules are critical to our current system of private enforcement and are largely unique to the American legal system. First and oldest is the "American rule," under which each side bears its own legal expenses. See Alyeska Pipeline Serv. Co. v. Wilderness Soc'y, 421 U.S. 240 (1975). Economic analysis suggests that the effect of this rule is to increase the incentive to bring an action that has a relatively low prospect of success at trial. See Shavell, Suit, Settlement, and Trial: A Theoretical Analysis Under Alternative Methods for the Allocation of Legal Costs, $11 \mathrm{~J}$. Legal Stud. 55 (1982).

Second, the "common fund" doctrine entitles a plaintiff who creates a fund that benefits others to recover attorney's fees out of the fund based on principles of unjust enrichment. This doctrine is an exception to the traditional "American rule." See Boeing Co. v. Van Gemert, 444 U.S. 472, 478-81 (1980). The "common fund" doctrine has long governed the award of attorney's fees in derivative suits and securities class actions. See Hornstein, The Counsel Fee in Stockholder's Derivative Suits, 39 Colum. L. Rev. 784 (1939).

Third, the contingent fee, which has long been permitted in the United States, see Findlater, The Proposed Revisions of DR 5-103(B): Champerty and Class Actions, 36 Bus. Law. 1667, 1669-70 (1981), enables a plaintiff's attorney to undertake litigation as a joint venturer with the client.

The final rule involves statutory "attorney fee shifting." Over the last several decades, a host of statutes have been enacted that authorize an award of attorney's fees to a successful plaintiff's attorney. One recent survey found 1974 such statutes at the state level alone and suggested that fee shifting is now at least as common as the traditional "American rule." See Note, State Attorney Fee Shifting Statutes: Are We Quietly Repealing the American Rule?, Law \& Contemp. Probs., Winter 1984, at 321.

3. The Supreme Court has, itself, revealed a more skeptical view of the class action plaintiff's attorney. In Blue Chip Stamps v. Manor Drug Stores, 421 U.S. 723, 739-40 (1975), the Court said:

There has been widespread recognition that litigation under Rule 10b-5 presents a danger of vexatiousness different in degree and in kind from that which accompanies litigation in general . . . . The very pendency of the law- 
sified, ${ }^{4}$ there has been a growing trend to reexamine and tighten these rules. This Article will argue, first, that this movement to limit private enforcement has proceeded to a considerable extent upon false premises and, second, that many of the deficiencies in the private attorney general's performance that have been noted by courts are the judically self-inflicted consequence of legal rules that establish serious misincentives. More generally, this Article will attempt to explain the behavior of professional plaintiff's attorneys who specialize in class and derivative litigation in terms of the incentives and organizational problems that they currently face.

Academic criticism of private enforcement has had at least three distinct themes. First, some critics, including this author, have argued that the legal rules governing the private attorney general have created misincentives that unnecessarily frustrate the utility of private enforcement. ${ }^{5}$ These critics have focused chiefly on the conflicts that arise be-

suit may frustrate or delay normal business activity of the defendant which is totally unrelated to the lawsuit.

Through this statement, the Court accepted the theory that nuisance actions give plaintiff's attorneys extortionate leverage over defendants. This Article examines that theory skeptically, but does not purport to refute it wholly. In light of Blue Chip, it is interesting to note the frequency with which judicial opinions favoring new restrictions on the availability of class actions or other remedies criticize the plaintiff's attorney. See Piambino v. Bailey, 757 F.2d 1112, 1143-46 (11th Cir. 1985); In re Fine Paper Antitrust Litig., 98 F.R.D. 48 (E.D. Pa. 1983), rev'd on other grounds, 751 F.2d 562 (3d Cir. 1984); In re Armored Car Antitrust Litig., 472 F. Supp. 1357, 1381-82, 1388-89 (N.D. Ga. 1979), aff'd in part, rev'd in part, 645 F.2d 488 (5th Cir. 1981); Foster v. Boise-Cascade, Inc., 420 F. Supp. 674, 680 (S.D. Tex. 1976), aff'd, 577 F.2d 335 (5th Cir. 1978); In re Penn Cent. Sec. Litig., 416 F. Supp. 907, 925 (E.D. Pa. 1976), rev'd on other grounds, 560 F.2d 1138 (3d Cir. 1977); cf. Eisen v. Carlisle \& Jacquelin, 391 F.2d 555, 57 I (2d Cir. 1968) (Lumbard, J., dissenting) ("[T]he only persons to gain from a class suit are not potential plaintiffs, but the attorneys who will represent them.").

4. From 1960 to 1983 , "the number of cases filed [annually] in the [federal] district courts more than tripled, roughly from 80,000 to 280,000 - a 250 percent increase, compared with less than 30 percent in the preceding quarter century." R. Posner, The Federal Courts: Crisis and Reform 63-64 (1985). Others argue that there has been no increase in the level of litigiousness in our society and that fewer disputes are being submitted to courts than in the past. See, e.g., Galanter, Reading the Landscape of Disputes: What We Know and Don't Know (And Think We Know) About Our Allegedly Contentious and Litigious Society, 31 UCLA L. Rev. 4, 5 (1983) (The "symbolic presence" of litigation has grown "even when direct personal experience of full-blown adjudication [is] less frequent.").

5. See Coffee, Rescuing the Private Attorney General: Why the Model of the Lawyer as Bounty Hunter 1s Not Working, 42 Md. L. Rev. 215 (1983) [hereinafter cited as Coffee, Private Attorney General]; Coffee, The Unfaithful Champion: The Plaintiff as Monitor in Shareholder Litigation, Law \& Contemp. Probs., Summer 1985, at 5 [hereinafter cited as Coffee, Plaintiff as Monitor]; Clermont \& Currivan, Improving on the Contingent Fee, 63 Cornell L. Rev. 529 (1978); Schwartz \& Mitchell, An Economic Analysis of the Contingent Fee in Personal-Injury Litigation, 22 Stan. L. Rev. 1125 (1970). For probably the first important effort to model the incentives that the law holds out to the private enforcer, see Dam, Class Actions: Efficiency, Compensation, Deterrence, and Conflict of Interest, 4 J. Legal Stud. 47 (1975). 
tween the interests of these attorneys and their clients in class and derivative actions, and on the disputes among plaintiff's attorneys that attend the organization, staffing, and financing of a large class action. In contrast, a second group of critics has expressed concern not that attorneys poorly serve their clients, but that the incentive to litigate may be inherently excessive, in large part because the parties to an action do not bear its public costs. ${ }^{6}$ This failure to internalize the full cost of litigation, including the costs of the judicial system, implies that litigation as a commodity is priced too cheaply. As a result, the demand for litigation is artificially inflated by a public subsidy equal to these costs, and the private incentive to litigate exceeds the social incentive. This analysis gives theoretical legitimacy to a critique increasingly heard in public discourse that the United States suffers from "hyperlexia" - that is, an excessive reliance on law and lawyers." Finally, a third set of critics discount the social benefits of litigation brought by private attorneys general. For example, some have analyzed the incentive for extortion in nuisance suits and concluded that rational, well-informed plaintiffs might bring an action that has no chance of success at trial in order to extort a recovery from the defendants. ${ }^{8}$ Others have argued that the benefits of derivative litigation appear to be insignificant at best, a conclusion based on the fact that the stock market apparently does not respond positively to news of an action's commencement. ${ }^{9}$ Viewed in this light, such litigation is arguably

6. See R. Posner, supra note 4, at 131-32; Shavell, The Social Versus the Private Incentive to Bring Suit in a Costly Legal System, $11 \mathrm{~J}$. Legal Stud. 333 (1982); L. Kaplow, Private Versus Social Costs in Bringing Suit (Discussion Paper No. 9, Harvard Law School Program of Law and Economics, May 1985) (forthcoming in $15 \mathrm{~J}$. Legal Stud., June 1986). Professors Kaplow and Shavell recognize that the social benefits of a suit can also exceed its private benefits. However, their accurate observation that litigation is subsidized places a burden on proponents of private enforcement to defend this subsidy. This Article suggests such a defense. Another related argument that explains why litigation incentives are excessive seems more dubious. Professors Landes and Posner contend that because the optimum legal penalty must exceed the social loss caused by wrongdoers in order to offset the fact that detection is uncertain, private enforcers overinvest in law enforcement. See Landes \& Posner, The Private Enforcement of Law, $4 \mathrm{~J}$. Legal Stud. 1, 38 (1975). This argument assumes that the private enforcer receives the penalty. In fact, if we recognize that the private enforcer is not the client, but rather the plaintiff's attorney, there is no necessary incentive to overinvest because the attorney receives only a fraction of the total recovery as his fee.

7. See Bok, A Flawed System of Law Practice and Training, 33 J. Legal Educ. 570 (1983). For more representative statements of the claim that there is too much litigation, see Manning, Hyperlexis: Our National Disease, 71 Nw. U.L. Rev. 767 (1977); Rosenberg, Let's Everybody Litigate?, 50 Tex. L. Rev. 1349 (1972). But cf. Galanter, supra note 4, at 36 (disputing the claim that there has been an increase in the rate of litigiousness).

8. See Rosenberg \& Shavell, A Model in Which Suits Are Brought for Their Nuisance Value, 5 Int'l Rev. L. \& Econ. 3 (1985); see also infra notes 93-94 and accompanying text (discussing the cost differential explanation of nuisance actions).

9. See Fischel \& Bradley, The Role of Liability Rules and the Derivative Suit in Corporate Law: A Theoretical and Empirical Analysis, 71 Cornell L. Rev. 261, 277-83 
not only excessively subsidized, but has a negative social utility. These contentions relate to a theme long debated in the legal literature: whether class and derivative actions brought against corporate officials consist disproportionately of frivolous "strike suits." 10

Taken together, this "new learning" concerning private enforcement conveys a pessimistic sense about the utility of the private attorney general mechanism. In time, these critiques may influence judicial and legislative decisions; already, there seems to be a significant trend toward curtailing private enforcement of law through class and deriva-

(1986). The claim that stock price studies prove the derivative action's lack of utility seems inherently suspect. First, stock prices should respond only to unforeseen developments because, in theory, the market price absorbs all available information. In many instances, the market may anticipate that a derivative action will be filed; in fact, the available empirical evidence suggests that such actions regularly follow in the wake of prior proceedings by the SEC or other governmental agencies. See infra notes 36-37 and accompanying text. Hence, the market price of a stock may already reflect the probability that an action will be filed, making further price adjustments on the day of filing unlikely.

Second, only a very small percentage of derivative actions (apparently less than one percent) result in litigated plaintiff victories. See infra notes 81-83 and accompanying text. There is also a pronounced tendency for such actions to end in collusive settlements, in which the corporation bears the high cost of the plaintiff's attorney's fee award. See infra notes 120-135 and accompanying text. Given this pattern, the market may simply expect that the action will result in a quiet, nonpecuniary settlement that benefits the attorneys more than the shareholders. Hence, the market should not react positively. This pattern, however, proves not that the derivative action lacks utility, but only that its potential utility has been frustrated by other legal rules that permit collusive settlements.

Finally and most fundamentally, the benefit of a derivative action may accrue less to the shareholders of the subject corporation and more to shareholders generally in the form of increased deterrence of management abuses. As a result, shareholders as a class could benefit even though a particular corporation's stock price declined because the corporation was compelled to incur litigation expenses in excess of the specific benefits it received. This general deterrent benefit is exceedingly hard to test empirically because it requires an examination not of the stock price of the subject company, but of the stock prices of all corporations affected by the action (or corporations whose managers believe themselves to be affected).

10. The Wood Report, which was prepared for the Chamber of Commerce of the State of New York, found that plaintiffs recovered in only 13 out of 573 derivative suits involving publicly held corporations. F. Wood, Survey and Report Regarding Stockholders' Derivative Suits 32 (1944). The Wood Report led to the adoption of "security for expenses" statutes desigued to curb derivative litigation. For similar and more recent criticisms of the derivative action, see the Business Roundtable, Statement of the Business Roundtable on the American Law Institute's Proposed "Principles of Corporate Governance and Structure" (1983); see also infra notes 81-83 and accompanying text (discussing empirical evidence of low success rates of plaintiffs in derivative actions). For a reexamination of the Wood Report's data, see Conard, A Behavioral Analysis of Directors' Liability for Negligence, 1972 Duke L.J. 895, 901. Defenders of derivative litigation have suggested that the "strike suit" is largely a mythical beast-"an over-the-hill dragon puffed into life to frighten courts away from deciding substantive issues." See W. Cary \& M. Eisenberg, Cases and Materials on Corporations 888 (5th ed. 1980). 
tive actions. A milestone in this trend came last year when, in Marek $v$. Chesny, ${ }^{11}$ the Supreme Court reinterpreted Rule 68 of the Federal Rules of Civil Procedure in a manner that may authorize partial fee shifting against a prevailing party when that party declined a settlement offer that was more favorable than the outcome obtained at trial. ${ }^{12}$ Although the Marek holding is limited to specific statutes, ${ }^{13}$ its impact upon plaintiff's attorneys could be enormous because they may face potential liability for the defendant's post-offer legal expenses if defense counsel merely follows the predictable stratagem of offering a small settlement. ${ }^{14}$ Similarly, the Supreme Court has begun to cast an increasingly

11. 105 S. Ct. 3012 (1985).

12. In Marek, the Supreme Court, though not shifting the defendant's fees against the plaintiff, construed Rule 68 to provide that a party who is statutorily entitled to a judicial award of attorney's fees forfeits that right when the party declines a settlement offer and then fails to do better at trial. Previously, the Court had not read the term "costs" in 28 U.S.C. $\$ 1927$ (1982) to include attorney's fees. See Roadway Express, Inc. v. Piper, 447 U.S. 752, 759-61 (1980). Although the holding in Marek applies only to certain federal statutes that both authorize fee shifting and define costs to include attorney's fees, the decision's logic seemingly requires a shifting of the losing party's post-offer fees if the losing party made a settlement offer superior to the judgment the winning party obtained at trial. Paradoxically, the result places a plaintiff's attorney in a more vulnerable position in those cases where Congress authorized fee shifting than where it did not, because only in the former case is the plaintiff exposed to liability for the defendant's typically larger post-offer legal expenses. From the standpoint of tliose who wish to minimize the federal court's caseload or reduce the rate of litigation for other reasons, Marek may encourage early settlements by introducing greater two-way fee shifting.

13. As Justice Brennan pointed out in an appendix to his dissent in Marek, there are at least 64 federal statutes that refer to attorney's fees as "costs," and hence would appear subject to fee-shifting offers under Rule 68. 105 S. Ct. at 3035-39.

14. Even outside the field of class actions, Rule 68 "redistributes wealth between plaintiffs and defendants." Miller, An Economic Analysis of Rule 68, $15 \mathrm{~J}$. Legal Stud. 93, 95 (1986). This condition is substantially aggravated in the context of class and derivative actions. Because the plaintiff in a class action or derivative suit frequently has only a nominal stake in the action's outcome, such a plaintiff would not rationally risk liability for the defendant's legal fees simply to obtain a trivial recovery on a individual basis. Although various means might be found by which the plaintiff's attorney could agree covertly to indemnify a nominal plaintiff, such techniques arguably offend legal ethics, which generally forbid attorneys from investing in actions. See Model Rules of Professional Conduct Rule 1.8(e), (j) (1983). Moreover, the attorney's own expected recovery from the action-the expected fee award-may often be less than the defendant's post-offer litigation expenses.

Tactically, a defendant in a class action could make a settlement offer well below the level justified by the case's litigation odds. The lead plaintiff would then know that he faced personal liability if he obtained a judgment smaller than the settlement offer. Besides converting one-way fee shifting in favor of the plaintiff into a system of two-way fee shifting, such an offer creates a conflict between the lead plaintiff and the rest of the class. For this reason, a revision of Rule 68 that was proposed by the Committce on Rules of Practice and Procedure of the Judicial Conference of the United States excluded class and derivative actions from its recommendation that post-offer fees be shifted. See Preliminary Draft of Proposed Amendments to the Federal Rules of Civil Procedure, 98 F.R.D. 339, 361-67 (1983). Yet the Supreme Court in Marek said nothing 
skeptical eye on the legal standards used to award plaintiff's attorney's fees. ${ }^{15}$ Even the Third Circuit, which originally authored the "lodestar" fee award formula that now prevails in federal courts, ${ }^{16}$ reexamined its own invention in 1985 and found it seriously deficient and subject to abuse. ${ }^{17}$ The Reagan administration's recent proposals, which would restrict the availability of treble damages in antitrust ac-

that would exclude class actions brought pursuant to specified federal statutes from its rule on fee shifting. However, in Delta Air Lines, Inc. v. August, 450 U.S. 346, 353-54 n.12 (1981), the Court raised, but refused to reach, the issue of whether "sham or token offer[s] by the defendant" should be given effect under Rule 68. See id. at 350 (Court declined to resolve "reasonableness" question).

15. In Blum v. Stenson, 465 U.S. 886, 897 (1984), the Supreme Court indicated that the award of a contingency bonus (or, in the Court's language, an "upward adjustment") to plaintiff's attorneys would rarely be appropriate, at least in the context of fee awards under the Civil Rights Attorney's Fees Awards Act of 1976, 42 U.S.C. $\$ 1988$ (1982). Previously, contingency bonuses had been regularly awarded to reflect the risk involved in taking an action on a contingent fee basis. See Leubsdorf, The Contingency Factor in Attorney Fee Awards, 90 Yale L.J. 473, 473 (1981). A year prior to Blum, the Court noted in Hensley v. Eckerhart, 461 U.S. 424, 434 (1983), that courts should give primary attention to the "results obtained" in determining fee awards. The full implications of this criterion may become more evident when the Court decides City of Riverside v. Rivera, 763 F.2d 1580 (9th Cir.), cert. granted, 106 S. Ct. 244 (1985), which poses the question of whether fee awards must be proportional to the judgment obtained. In Rivera, a case involving police harassment of Hispanics, fees of $\$ 245,456.23$ were awarded at trial and upheld by the Ninth Circuit, notwithstanding the fact that the jury award to the plaintiffs was only $\$ 33,350$. See id. at 1581, 1583; Lauter, Court to Examine "Proportionality" Fee Issues, Nat'l L.J., Nov. 4, 1985, at 5, col. 1. Although these civil rights cases pose different issues, restrictive precedents in this area will likely impact class and derivative actions. Finally, in Evans v. Jeff D., 54 U.S.L.W. 4359 (April 21,1986 ), the Supreme Court has upheld the practice of defendants making settlement offers that are conditional on the plaintiff's attorney waiving any statutory claim for attorneys' fees. Ex ante, the impact of legitimizing fee waivers should again be to chill the plaintiff's attorney's incentive (although this impact will arise only in those contexts where statutory fee shifting is authorized).

16. The key decisions adopting the lodestar formula were Lindy Bros. Builders, Inc. v. American Radiator \& Standard Sanitary Corp. (Lindy I), 487 F.2d 161 (3d Cir. 1973), and Lindy Bros. Builders, Inc. v. American Radiator \& Standard Sanitary Corp. (Lindy II), 540 F.2d 102 (3d Cir. 1976). Essentially, these decisions adopted the lodestar criteria for fee awards specified in the Manual for Complex Litigation, Second $\$ 24.12$ (1985), which had been revised in 1973 to suggest that fee awards be primarily computed by multiplying the attorney's time reasonably expended in an action and the attorney's normal billing rate. The Supreme Court has accepted the lodestar formula as the starting point for determining fee awards, at least in the civil rights context. See Hensley v. Eckerhart, 461 U.S. 424, 433 (1983). For a fuller explanation of this formula, see Leubsdorf, supra note 15 , at $477-82$.

17. A Third Circuit task force has concluded that the lodestar formula increases the use of judicial resources, encourages attorneys to bill excessive hours, and discourages early settlements. See Revised Fee Awards Standards Offered by Third Circuit Panel, Legal Times, Nov. 25, 1985, at 3, col. 1. The Task Force recommended a return to the percentage of the recovery fee formula in cases involving a settlement fund. See Court Awarded Attorneys Fees: Report of the Third Circuit Task Force 27 (Oct. 8, 1985) (copy on file at the offices of the Columbia Law Review) [hereinafter cited as Task Force]. 
tions and would limit both damage awards and attorney's fee recoveries more generally, are also clearly predicated upon the perception that there is an excessive incentive to litigate. ${ }^{18}$ All these developmentsfee shifting against the plaintiff, the upholding of fee waivers, the restriction of treble damages, and the use of more parsimonious fee award standards-can be justified if one believes there is an excessive incentive to litigate.

This Article offers an alternative perspective. It suggests that the private incentives to litigate may often be inadequate in terms of their social benefits. Indeed, any conclusion that there is an "excessive" incentive to litigate cannot be based simply on the fact that parties do not bear the full costs of litigation. One must start by specifying what the incentives are to litigate, and this depends on whose incentives control: is it the lawyer or the client who determines the level of investment in an action? Part I of this Article examines the debate over the difference between the private and social incentives to litigate in light of the fact that the attorney's interests typically control class and derivative actions. Once we understand that the plaintiff's attorney in these actions behaves as a risk-taking entrepreneur, there are reasons to believe that the private incentives for much litigation may be inadequate from a social cost perspective. Part II then employs a recently developed model of litigation ${ }^{19}$ to examine the existing theories of the nuisance action. This analysis suggests that neither the evidence nor the existing theory provides persuasive support for the claim that plaintiff's attorneys have strong incentives to bring nonmeritorious actions. In particular, the fact that these plaintiffs win relatively few litigated judgments is found

18. The Reagan cabinet has proposed the elimination of treble damages in some antitrust suits. See Pasztor, Cabinet Maps Easing of Antitrust Law; Business Groups Think Plan Is Too Bold, Wall St. J., Dec. 6, 1985, at 6, col. 1. The Committee on Antitrust and Trade Regulation of the Association of the Bar of the City of New York had earlier taken a similar position favoring the abolition of treble damages for certain antitrust violations. See Report on Treble Damages, 40 Rec. A.B. City N.Y. 647, 660 (1985). One justification cited by the Committee was that treble damages encouraged strike suits. Id. at 656 . The Reagan administration has also supported limits on jury awards and attorney's fees. See Pear, Administration Submits Plan to Reduce Damage Awards, N.Y. Times, May 1, 1986, at B9, col. 1 (legislation proposed to limit contingent fees to $25 \%$ of the first $\$ 100,000$ recovered, then $20 \%$ of the second $\$ 100,000,15 \%$ of the third $\$ 100,000$, and $10 \%$ of the remainder).

19. Most economists have accepted a model of litigation under which all suits are settled except those where one side is excessively optimistic. See, e.g., Gould, The Economics of Legal Conflicts, 2 J. Legal Stud. 279, 288-91 (1973); Landes, An Economic Analysis of the Courts, 14 J.L. \& Econ. 61, 66-69 (1971); Posner, An Economic Approach to Legal Procedure and Judicial Administration, 2 J. Legal Stud. 399, 417-20 (1973); Priest \& Klein, The Selection of Disputes for Litigation, $13 \mathrm{~J}$. Legal Stud. 1, 12-15 (1984). But of. Cooter, Marks \& Mnookin, Bargaining in the Shadow of the Law: A Testable Model of Strategic Behavior, I I J. Legal Stud. 225, 226 (1982) (efforts to obtain larger share of stakes in a dispute are primary cause of trials). For a fuller discussion of the "optimism model," see infra notes 87-91 and accompanying text. 
to be consistent with economic theory, rather than supportive of the proposition that these actions are disproportionately frivolous.

Finally, Part III views the plaintiff's attorney as a utility-maximizing entrepreneur who manages a portfolio of actions and thus makes litigation decisions in an individual case based upon their overall impact on the portfolio. From this portfolio theory perspective, it is also possible to understand why plaintiff's attorneys might bring and maintain actions that have comparatively low prospects for success at trial. The implications of this theory, however, tend to conflict with the observed reality. They suggest that plaintiff's attorneys should form very large law firms to reduce risk through diversification when, in fact, these lawyers appear unable to organize on such a scale. This inability of plaintiff's attorneys to form optimally-sized firms undercuts the claim that there is an excessive incentive to litigate; instead, it suggests that plaintiff's attorneys are biased in favor of early settlements. The inability also suggests that a simple portfolio model of the plaintiff's firm is unrealistic at present.

Other explanations seem better able to account for attorneys bringing nonmeritorious actions. One such explanation is that a significant cost differential favoring plaintiffs makes extortionate litigation feasible. ${ }^{20}$ However, this Article submits that principal-agent problems create a countervailing "benefit differential" that favors defendants in class action litigation, thus making the extortion thesis less plausible than it first appears. Ultimately, the most persuasive account of why class actions frequently produce unsatisfactory results is the hypothesis that such actions are uniquely vulnerable to collusive settlements that benefit plaintiff's attorneys rather than their clients. This conclusion suggests that legal as well as economic forces are at the root of the problem.

\section{The Incentive to Litigate in Class and Derivative Actions}

In those areas of litigation where a client cannot closely monitor or control the plaintiff's attorney's conduct, the plaintiff's attorney's incentives will shape important litigation decisions. Only after those incentives are understood can we consider the available means by which the law can seek to induce the attorney to perform in a manner that approximates the socially efficient outcome.

\section{A. Principal and Agent: Who's in Control?}

In theory, a fundamental premise of American legal ethics is that clients, not their attorneys, should define litigation objectives. ${ }^{21}$ Yet, in the context of class and derivative actions, it is well understood that the

20. See Rosenberg \& Shavell, supra note 8, at 4-5.

21. See Model Rules of Professional Conduct Rule 1.2(a) (1983) ("A lawyer shall abide by a client's decisions concerning the objectives of representation . . . ."); see 
actual client generally has only a nominal stake in the outcome of the litigation. Empirical studies have shown this, ${ }^{22}$ and courts, when dissatisfied with the performance of plaintiff's attorneys, are prone to emphasize that the plaintiff's attorney has no "true" identifiable client. ${ }^{23}$ Despite these grumblings, our legal system has long accepted, if somewhat uneasily, the concept of the plaintiff's attorney as an entrepreneur who performs the socially useful function of deterring undesirable conduct. This acceptance is manifested in a variety of ways: by permitting the attorney to advance the expenses of the litigation and receive reimbursement only if successful; ${ }^{24}$ by sometimes permitting the attorney to settle a class or derivative action over the objections of the actual client who is serving as representative of the class; ${ }^{25}$ and by allowing the use of fee formulas that view "the lawyer as a calculating entrepreneur regulated by calculating judges." 26 Thus, although our law publicly ex-

also Rhode, Class Conflicts in Class Actions, 34 Stan. L. Rev. 1183, 1183 (1982) (noting difficulties in applying principle of client control to context of class litigation).

22. The Wood Report, which surveyed nearly 1400 derivative actions filed in several New York state and federal courts during the 1930s and early 1940 s, reported that the representative plaintiff typically had very small stakes in the outcome. See F. Wood, supra note 10, at 45-46. More recent empirical research has not challenged this finding. See Garth, Nagel \& Plager, Empirical Research and the Shareholder Derivative Suit: Toward a Better-Informed Debate, Law \& Contemp. Probs., Summer 1985, at 137, $142-43$.

23. See Piambino v. Bailey, 757 F.2d 1112, 1144 (11th Cir. 1985); Foster v. BoiseCascade, Inc., 420 F. Supp. 674, 681 (S.D. Tex. 1976), aff'd, 577 F.2d 335 (5th Cir. 1978).

24. See Model Rules of Professional Conduct Rule 1.8(e)(1) (1983) (lawyer "may advance court costs and expenses of litigation, the repayment of which may be contingent on the outcome of the matter"); Findlater, supra note 2, at 1669.

25. See Morris, A View of Representative Actions, Derivative and Class, from a Plaintiff's Attorney's Vantage Point, 3 Del. J. Corp. L. 273, 276 (1978) (discussing conflict between attorney and client in Saylor v. Livesay, 274 F. Supp. 253 (S.D.N.Y. 1967), rev'd on other grounds, 391 F.2d 965 (2d Cir. 1968)).

It is generally recognized that counsel's fiduciary obligation runs to the class and not simply to the named plaintiff. Thus, courts have sided with class counsel where conflicts arise between counsel and the lead plaintiff in a class action. See Greenfield v. Villager Indus., Inc., 483 F.2d 824, 832 n.9 (3d Cir. 1973); Handler, Edgar \& Settle, Public Interest Law and Employment Discrimination, in Public Interest Law: An Economic and Institutional Analysis 251, 274 (1978) (discussing claimed ability of public interest law firms to manage litigation without client direction); Rhode, supra note 21, at 1202-04.

26. Leubsdorf, supra note 15 , at 481 (discussing courts' rationale for granting attorneys a contingency bonus in addition to fees calculated under the lodestar formula).

American law essentially uses two different formulas to award plaintiff's attorney's fees. The lodestar formula awards the attorney a fee based on the time reasonably expended on an action. In contrast, the percentage of the recovery formula gives the attorney a portion of the fund that his efforts have "salvaged." In "common fund" cases, the Supreme Court has held that the "reasonable fee is based on a percentage of the fund bestowed on the class." Blum v. Stenson, 465 U.S. 886, 900 n.16 (1984). In fee shifting cases, however, the federal courts are using the lodestar formula. Id. at 893-94; Leubsdorf, supra note 15 , at $478 \& \mathrm{nn} .29-32$. Still, despite the vast theoretical differences between the two fee formulas, empirical surveys of securities class actions and 
presses homage to individual clients, it privately recognizes their limited relevance in this context.

Although this legal structure is largely unparalleled in other common law systems, ${ }^{27}$ it has its obvious advantages. First, it enables clients who are dispersed or have suffered relatively small injuries to receive legal representation without incurring the substantial transaction costs of coordination. Absent such a system, a classic "free rider" problem would arise because litigation is a form of "public good" in which the benefits of an action accrue to persons who are not required to bear their share of the action's costs. This means that litigation would be predictably underfunded, from the clients' perspective, if the clients had to take collective action. ${ }^{28}$ Second, because the attorney as private enforcer looks to the court, not the client, to award him a fee if successful, the attorney can find the legal violation first and the client second. In principle, this system should encourage the attorney to invest in search costs and seek out violations of the law that are profitable for him to challenge, rather than wait passively for an aggrieved client to arrive at his door. Thus, the attorney becomes a "bounty hunter"or, less pejoratively, an independent monitoring force-motivated to prosecute legal violations still unknown to prospective clients.

However, this system also creates the potential for both opportunism ${ }^{29}$ and overenforcement. The first of these dangers arises because,

derivative actions have found that courts award approximately the same percentage of the total recovery under either formula, at least in actions involving more than $\$ 1,000,000$. See Mowrey, Attorneys Fees in Securities Class Action and Derivative Suits, 3 J. Corp. L. 267, 345-47 (1978). Historically, fee awards have ranged between $20 \%$ and $30 \%$ of recoveries below $\$ 1,000,000$, and have declined as a percentage of the recovery when the recovery increases beyond $\$ 1,000,000$. See Cole, Counsel Fees in Stockholders' Derivative and Class Actions-Hornstein Revisited, 6 U. Rich. L. Rev. 259, 273-75, 281 (1972) (fee awards average $20 \%$ and decline as recoveries increase); Mowrey, supra, at 334-38. Courts frequently calculate a fee under the lodestar formula and then note that the fee award, as so calculated, does not exceed $25 \%$ of the total recovery. See In re Warner Communications Sec. Litig., 618 F. Supp. 735, 749-50 (S.D.N.Y. 1985) (reviewing recent fee awards in securties class actions in the Second Circuit); Meshel v. Nutri/System, Inc., [1984-1985 Transfer Binder] Fed. Sec. L. Rep. (CCH) ๆ 91,890 , at 90,428 (E.D. Pa. May 15, 1984).

27. English law, for example, does not follow the American rule, but instead provides for dual fee shifting under which the loser pays the winner's legal fees. See Alyeska Pipeline Serv. Co. v. Wilderness Soc'y, 421 U.S. 240, 247 (1975). Similarly, English law does not tolerate the contingent fee. See Findlater, supra note 2, at 1668-69 \& n.10. The class action is also a distinctly American invention. See Developments in the Law-Class Actions, 89 Harv. L. Rev. 1318, 1321 (1976).

28. See Scott, Corporation Law and the American Law Institute Corporate Governance Project, 35 Stan. L. Rev. 927, 940 (1983). If all the persons who recover in a class action were not required to share its costs, the lead plaintiff would probably only invest funds in the action up to the level of his expected benefit. To avoid such underfunding, the "common fund" doctrine equitably taxes all who share in a class action recovery for a portion of its costs. In the derivative suit context, the same result is achieved by requiring the corporation to pay the attorney's fees of a "successful" lead plaintiff.

29. The term "opportunism" refers to behavior that Professor Oliver Williamson 
in economic terms, there are high "agency costs" associated with class and derivative actions. ${ }^{30}$ To be sure, the magnitude of these costs will vary depending upon a variety of factors. In much "public interest" litigation, the structure of the "public interest" law firm-in particular, its independent board, its more limited ability to pay out earnings to its attorneys, and its need to raise funds from donors in the future-may substitute for client control and produce substantial monitoring of attorney opportunism. In other areas, such as employment discrimination litigation, client control may be relatively stronger than in the typical class action either because of a greater financial injury per client (thereby encouraging closer monitoring of the attorney) or because of a subjective, nonmonetary component to the injury that produces the same effect. ${ }^{31}$

The second danger-overenforcement-arises because the unconstrained attorney may be motivated to sue where the client would not. ${ }^{32}$ Although the rational plaintiff's attorney would consider only the immediate payoff, the client may be concerned about the longer-term effects of litigation. For example, a plaintiff's attorney might commence a derivative suit against a corporation's officers and directors for a negligent business decision whenever the expected settlement would justify a fee that covered the attorney's opportunity costs. The shareholders, however, might rationally fear that such litigation would make directors excessively risk averse in the long-run. ${ }^{33}$ Similarly, in

describes as "self-interest seeking with guile." Williamson, The Modern Corporation: Origins, Evolution, Attributes, 19 J. Econ. Lit. 1537, I545 \& n.12 (198I). It assumes that agents will not abide by the terms of their contractual relationships with their principals, but will covertly pursue their own interests at their principals' expense. The term is appropriate here because it suggests behavior that is more disingenuous than unlawful or corrupt.

30. The term "agency costs" refers to both the costs the principal must incur to keep an agent loyal and to the losses that occur as a result of agent disloyalty that are not worth preventing. See Jensen \& Meckling, Theory of The Firm: Managerial Behavior, Agency Costs and Ownership Structure, 3 J. Fin. Econ. 305, 308-09 (1976). Once "agency costs" become very high, it is simpler to view attorneys as independent actors, even though they remain, to some degree, ultimately accountable to their clients.

31. A plaintiff may be motivated by a belief that he is contributing to an important social movement in a civil rights, employment discrimination, or environmental class action, but it is doubtful that such "psychic income" is a significant factor in an antitrust or securities class action, or in a derivative suit.

32. See Landes \& Posner, supra note 6, at 15 (arguing that because the price paid to the private enforcer does not decline once an optimum level of enforcement is achieved, there will be an excessive level of enforcement activity). On a more practical level, this problem of overenforcement can arise in a derivative action because the fee award is based on the gross recovery. Such a formula does not reflect the actual net recovery, if any, to the corporation after subtraction of the corporation's own litigation expenses, the indemnification payments made to the individual defendants, and the imputed costs associated with lost executive time.

33. This author has argued elsewhere that directors make "poor cost avoiders" with respect to corporate losses flowing from negligent decision making and hence can be rendered excessively risk averse (in terms of the desires of shareholders, who hold 
other contexts, shareholders may fear reprisals or counterclaims which could produce liabilities that are not borne by the plaintiff's attorney. ${ }^{34}$ Finally, overenforcement might result when a court awards attorney's fees based primarily on the time expended by the attorney, because such a fee formula creates an incentive to continue litigating a case well past the point at which the marginal costs of such effort equal the marginal returns generated thereby. ${ }^{35}$

What happens when client control is so weak as to make the attorney virtually an independent entrepreneur? In some areas of contemporary litigation, the pattern is typically one of the lawyer finding the client, rather than vice versa. A principal characteristic of these areas is that plaintiff's attorneys typically have low search costs. That is, plaintiff's attorneys can discover the existence of potentially meritorious legal claims at low cost to themselves. As an entrepreneur who is compensated only when successful, the plaintiff's attorney bears the costs of failure and seeks to minimize those costs by free riding on the monitoring efforts of others. The classic illustration of this pattern is in the field of antitrust enforcement, where private antitrust class actions have tended to piggyback on a prior governmental proceeding (such as a grand jury indictment or a Federal Trade Commission proceeding). ${ }^{36}$

diversified portfolios). See Coffee, Litigation and Corporate Governance: An Essay on Steering Between Scylla and Charybdis, 52 Geo. Wash. L. Rev. 789, 801-03 (1984). Another example might be a derivative suit brought by a small shareholder to enjoin questionable corporate payments in foreign countries. Although the payments may be illegal and injurious to United States foreign policy interests, they could be highly profitable to the corporation, and it is far from clear that shareholders collectively desire that such illegal action be enjoined.

34. Consider, for example, a plaintiff's attorney who wishes to bring an antitrust claim derivatively on $^{2}$ behalf of a corporation in which he holds a small stock interest. The claim may be meritorious, but the corporation may not wish to assert it because it will trigger a meritorious counterclaim (hypothetically, for trade secret theft). Here, the attorney's rational self-interest differs from the corporation's. Traditionally, the law has closely restricted the ability of shareholders to compel a corporation to sue a third party. See Ash v. IBM, 353 F.2d 491 (3d Cir. I965), cert. denied, 384 U.S. 927 (1966).

35. In principle, attorneys should continue to litigate a case so long as they are covering their opportunity costs. See Fignre A, infra text accompanying note 57 ; infra notes 56-57 and accompanying text.

36. See Coffee, Private Attorney General, supra note 5, at 222 n.16. Although the conventional wisdom has long been that class actions tend to "tag along" on the heels of governmentally initiated suits, a recent study of antitrust litigation by Professors Kauper and Snyder has placed this figure at "[l]ess than $20 \%$ of private antitrust actions filed between 1976 and 1983." See Moore, Data Galore in Georgetown Damage Study, Legal Times, Nov. 4, 1985, at 24, col. 4. However, these authors also note that a 1965 study placed the percentage at $75 \%$ for actions filed prior to 1960 . Id. This difference is probably explained both by the increasing percentage of nonclass action antitrust litigation and by the recent decline in government initiated suits. Nonclass action antitrnst litigation is very different from class action litigation because the former typically involves larger clients who can monitor their attorneys. Other studies have found "a striking correlation between the plaintiffs' success and the existence of a governmental proceeding." DuVal, The Class Action as an Antitrust Enforcement Device: The Chi- 
Other highly visible events may also signal the plaintiff's attorney. For example, a dramatic market decline in a corporation's stock value may lead the plaintiff's attorney to infer the existence of previously undisclosed and material adverse information. The plaintiff's attorney will thus be motivated to search for a securities law violation. The mass tort, such as an airplane crash or a toxic disaster, provides another obvious example. Similarly, a publicized takeover attempt may lead to a "greenmail" transaction, the adoption of a "poison pill," or some other defensive measure by the board of directors of a target corporation, thereby indicating the potential for a derivative suit.

Empirical evidence suggests that such dramatic, highly visible events underlie most securities class actions and derivative suits. ${ }^{37}$ The data confirm a basic fact about entrepreneurial plaintiff's attorneys: they gravitate to those areas where search costs are lowest. Thus, an entrepreneurially motivated system of private enforcement is likely to work well in areas where search costs are low, but considerably less well where such costs are high and the attorney must invest significant funds before discovering legal violations.

Once the plaintiff's attorney has decided to bring suit, identifying and securing a nominal client is often only a necessary procedural step that seldom poses a substantial barrier for the experienced professional. In the securities and derivative suit areas, there are well-known individuals who possess broad (but thin) securities portfolios and have served as the lead plaintiff in numerous previous class actions. ${ }^{38}$ Formerly, some plaintiff's law firms even invested their own firm's profitsharing plan broadly in the stocks of numerous corporations in order to have an in-house plaintiff at hand. ${ }^{39}$ Although the payment of a for-

cago Experience (1I), 1976 Am. Bar Found. Research J. 1273, 1282; accord Wolfram, The Antibiotics Class Actions, 1976 Am. Bar Found. Research J. 253, 258-59 (FTC guilty verdict triggered filing of actions nationwide).

37. One empirical study of class and derivative suits found a marked tendency for them to follow on the heels of a "dramatic event." See Kennedy, Securities Class and Derivative Actions in the United States District Court for the Northern District of Texas: An Empirical Study, 14 Hous. L. Rev. 769, 807, 824 (1977) (finding that 50\% of the class and derivative actions surveyed had piggybacked on prior SEC or bankruptcy proceedings). In effect, these governmental proceedings reduce the private enforcer's search costs.

38. A near legendary example is a Mr. Harry Lewis, who by his own account in sworn depositions has served as the named plaintiff in "several hundred" filed cases and at least $\mathbf{5 2}$ reported corporate and securities law decisions in federal courts. See Branson, The American Law Institute Principles of Corporate Governance and the Derivative Action: A View from the Other Side, 2 n.9 (1985) (unpublished manuscript) (upcoming in Wash \& Lee L. Rev.) What motivates such a client? Some suspect there are secret fee-splitting arrangements in such cases, but it is also possible that professional plaintiffs simply enjoy litigation and can engage in it relatively costlessly.

39. See, e.g., Lowenschuss v. Kane, 520 F.2d 255, 259 n.2 (2d Cir. 1975) (plaintiff was attorney whose firm's pension plan invested in takeover target). In fact, any "cooperative" pension or profit-sharing plan can provide the plaintiff's attorney with a client that can obtain standing to sue many companies in the stock market. Cf. Tanzer v. Inter- 
warding fee is generally forbidden by legal ethics, ${ }^{40}$ there is reason to believe in some fields that nonspecialist attorneys often direct a client who has legal standing to a plaintiff's attorney in return for such a fee (or for a nominal role in the case that will entitle the nonspecialist attorney to a share of any court awarded attorney's fees). ${ }^{41}$

Although the existence of this informal network of relationships between attorneys and "in-house" clients that facilitates the filing of class actions, it hardly means that the client is purely an anachronism. For instance, to the extent that an informed client is available, his presence may greatly reduce search and preparation costs. But unless the client is willing to invest in the action by bearing litigation expenses, the attorney will still make the critical investment decisions, thereby reversing the normal roles of principal and agent. When the client is neither a potentially valuable witness nor a co-investor in the action, his role may often be only that of a "ticket of admission" by which the plaintiff's attorney can join the caucus of attorneys who gather to organize a class action. ${ }^{42}$

As a normative matter, such a description of the attorney-client relationship may seem offensive to those accustomed to viewing the relationship as a fiduciary one. Yet for analytical purposes, one better understands the behavior of the plaintiff's attorney in class and deriva-

national Gen. Indus., Inc., 379 A.2d 1121 (Del. 1977) (plaintiffs were trustees of "Tanzer Economic Associates, Inc. Profit Sharing Plan"). Recent interpretations of legal ethics have indicated that a law firm cannot represent itself or its affiliates. See Kramer v. Scientific Control Corp., [1975-1976 Transfer Binder] Fed. Sec. L. Rep. (CCH) I 95,530 (3d Cir. 1976); cf. Lorber v. Beebe, 407 F. Supp. 279, 293 (S.D.N.Y. 1975) (partner of attorney-class representative disqualified from serving as counsel for the class). There is no apparent basis for distinguishing between the disqualification of a lawyer's spouse and other affiliates, such as a controlled corporation or a trust. Frequently, however, one plaintiff's attorney will serve as a client for another. See, e.g., Weiss v. Temporary Inv. Fund, Inc., 692 F.2d 928 (3d Cir. 1982) (Mr. Melvyn Weiss is a well-known securities plaintiff's attorney.).

40. See Model Rules of Professional Conduct Rule 1.5(e) (1983) (fee division between "lawyers who are not in the same firm" prohibited unless, inter alia, client consent is obtained and "each lawyer assumes joint responsibility for the representation"). Client consent would seem impossible to obtain in a class action unless the court consents on behalf of the class.

41. See Coffee, Private Attorney General, supra note 5, at 252-61 (describing system of reciprocal referrals and work assignments based on a patronage-like arrangement in the Fine Paper antitrust case).

42. Historically, the standard practice in the organization of a large class action was to permit the plaintiff's attorneys to elect their own lead counsel. See Manual for Complex Litigation $\S 1.92$ (5th ed. 1981) (advising trial court not to select lead counsel for the class but to request that plaintiff's attorneys select such counsel). Recently, judges have been given greater authority to select attorneys "responsible for various duties." Manual for Complex Litigation, Second, supra note 16, § 20.224. Judges, however, must "properly" continue "to give special consideration to the suggestions of counsel" in determining an attorney's role in a class action. Id. Of course, the lead attorney, after designation, must make litigation decisions based upon "concensus" and "compromise" with other attorneys in the group. Id. $\S 20.222$. 
tive actions if one views him not as an agent, but more as an entrepreneur who regards a litigation as a risky asset that requires continuing investment decisions. Furthermore, a purely fiduciary perspective is misleading because it assumes that the client's preferences with respect to when an action should be settled are exogenously determined, when, in fact, they are largely influenced by the fee award formula adopted by the court. ${ }^{43}$ The real question, then, is what fee award formula should courts choose? This question cannot be sensibly answered by considering only the client's interest. Rather, social costs must also be analyzed.

\section{B. The Disparity Between the Private and Social Incentive to Litigate}

In a stimulating article, Professor Shavell contends that the private and social incentives to bring suit bear no necessary relationship to each other. ${ }^{44}$ In particular, the social costs of litigation can often exceed the private costs because the parties to the action do not bear the costs of the judicial system. Under these circumstances, an externality arises because the private conduct that is encouraged imposes net costs on society. Others have questioned this externality analysis. They argue that rational defendants will incorporate ex ante the risk of civil liability into their production decisions and restrict output to the level at which the expected damages they cause just equal the plaintiffs' cost of bringing suit. ${ }^{45}$ At this equilibrium level, Peter Menell argues that there is no incentive for any plaintiff to bring suit, and hence no divergence exists between the private and social incentives to litigate, because "the structure of the legal system implicitly internalizes the costs of litigation." 46 Still, the range of disagreement between the two sides in this debate is a limited one. Professor Shavell's analysis suggests that there is likely to be an excessive incentive to litigate, ${ }^{47}$ while Menell's "suit preclusion equilibrium" analysis implies that the private and social incentives may be equivalent. Neither position, however, leads one to anticipate that there may generally be an inadequate incentive to litigate. Indeed, a third participant in this debate, Louis Kaplow,

43. This can be most easily understood in terms of Figure A, infra text accompanying note 57 . Under the percentage of the recovery formula, the client's recovery is maximized at point $X$. In contrast, under the lodestar formula, the client might find its net recovery (after legal expenses) maximized at an earlier or later point, depending on the relative slopes of the $O$-line and the $S$-curve. Thus, the client's preferences, as well as the attorney's, are shaped by the choice of the fee award formula.

44. See Shavell, supra note 6 , at 334 .

45. See Menell, A Note on Private Versus Social Incentives to Sue in a Costly Legal System, 12 J. Legal Stud. 41 (1983).

46. Id. at 52.

47. Professor Shavell has informed this author that in his view the social benefits of litigation could exceed the private benefits in some instances. Presumably an illustration would be where the action generates some deterrent benefits that cause others to desist from a course of conduct that would impose externalities on society. Still, the novel point in his analysis is the recognition that the costs of the judicial system borne by the state amount to a public subsidy for litigation. 
has argued that, even under Menell's analysis, it could still be "efficient for society to adopt legal rules that prohibit or otherwise discourage suit "48

But now introduce into this calculus a new variable: a serious principal-agent problem that gives the plaintiff's attorney, not the client, the real discretion as to whether to commence suit. This is the likely situation in class and derivative actions where the number of clients is large and the individual injuries small. Under the Menell-Kaplow analysis, it is assumed that plaintiffs will sue if their gross damages exceed their litigation costs. ${ }^{49}$ Because the class action device lowers plaintiffs' litigation costs below the level that would be incurred by bringing individual suits, the class action reduces the level of damages necessary to produce litigation. However, litigation must be viewed as a continuing investment decision, ${ }^{50}$ and plaintiff's attorneys have reason to be more hesitant to invest in an action than do their clients. Historically, courts have awarded plaintiff's attorneys in class and derivative actions fees that have ranged between twenty and thirty percent of recoveries. ${ }^{51}$

48. L. Kaplow, supra note 6, at 6 (emphasis in original). Professor Kaplow's analysis emphasizes that the private benefits of an action can exceed its private costs even though the action's social costs exceed its social benefits. His numerical illustration of this point largely depends on the existence of a litigation cost differential that favors plaintiffs. This Article argues that, in the context of class action litigation, any possible cost differential may be offset by a benefit differential that favors defendants. See infra notes 93-97 and accompanying text. This benefit differential, which results from the principal-agent problem, renders even more indeterminate the question of whether litigation incentives are excessive or inadequate.

49. Professor Shavell also assumes that a plaintiff will sue if, and only if, damages exceed the plaintiff's litigation costs. See L. Kaplow, supra note 6, at 4 (summarizing positions). This analysis seems basically correct, but it is subject to some exceptions. First, plaintiffs may engage in bluffing behavior. Second, plaintiffs may incur lower litigation expenses than defendants, thus possibly giving plaintiffs some negotiating leverage, even though litigation costs exceed the likely recovery. Ironically, this second possibility has been emphasized by Professor Shavell in his later work on nuisance actions. See Rosenberg \& Shavell, supra note 8, at 9-10. Although these factors might lead a plaintiff to sue even when damages do not exceed litigation expenses, they are at least partially offset by a contrary factor: the time value of money. That is, given the general unavailability of prejudgment interest, plaintiffs should sue only if their expected damage recovery, discounted by the period of its deferral, exceeds their expected litigation expenses. See infra text following note 54 .

50. Empirical work has stressed the need to view litigation as an investment process. See Trubek, Sarat, Felstiner, Kritzer \& Grossman, The Costs of Ordinary Litigation, 31 UCLA L. Rev. 72 (1983).

51. For discussion of fee awards in securities class actions and derivative suits, see supra note 26. In the antitrust context, where there is statutory fee shifting in favor of plaintiffs, a recent Georgetown University study found that plaintiff's attorney's fees averaged $20.2 \%(\$ 58,000)$ of the total recovery in non-Multi-District Litigation (nonMDL), but that their fee award fell to an average level of $8.3 \%(\$ 4,000,000)$ in typical Multi-District Litigation (MDL) cases. See S. Salop \& L. White, Private Antitrust Litigation: An Introduction and Framework 14-15 (Sept. 1985) (unpublished manuscript) (copy on file at the offices of the Columbia Law Review). This substantial difference may be attributable to the much larger size of the recovery in MDL cases $(\$ 48,000,000$ versus 
Moreover, fee awards have not been a constant percentage of recoveries, but rather have tended to decline as recovery size increases, thereby inclining plaintiff's attorneys to settle more "cheaply" as the damages involved increase. ${ }^{52}$

If we assume that the plaintiff's attorney acts as a rational entrepreneur in deciding to bring, maintain, or settle litigation, it follows that investment in class and derivative actions will tend to be underfunded in terms of the clients' preferences. The key point is that the litigation stakes are asymmetric, with the defendant focusing on the judgment or settlement and the plaintiff's attorney focusing on the fee, which is typically a declining percentage of the recovery. Thus, while Menell postulates a suit preclusion equilibrium under which defendants limit their harm-producing conduct to a level equal to the plaintiffs' litigation costs, ${ }^{53}$ their analysis ignores the agency costs inherent in the attorneyclient relationship. Once these costs are accounted for, it is not the plaintiffs' damages but the attorney's recovery that establishes the equilibrium level.

To illustrate this with an initially oversimplified example, assume

$\$ 287,000$ in non-MDL cases). Id. For purposes of this Article, the MDL context seems the more accurate proxy for class action litigation in which the clients are unable to constrain their attorney. In any event, a plaintiff's attorney who sees a fee award of about $8 \%$ to $10 \%$ of the expected recovery has far less incentive to invest in the action than do the defendants who bear the full cost of the settlement or final judgment (including, in the latter case, the plaintiff's attorney's fee as well).

52. See Cole, supra note 26, at 274-75; Mowrey, supra note 26, at 337, 343-48. The fee awards in 19 securities class actions are reviewed in In re Warner Communications Sec. Litig., 618 F. Supp. 735, 749-50 (S.D.N.Y. 1985). The Georgetown data on antitrust actions also show that fee awards fall as a percentage of the recovery in larger cases. See S. Salop \& L. White, supra note 5I, at 12-I4. The implication is that the bigger the action, the greater will be the tendency for underfunding and cheap settlements. The significance of this tendency for underfunding is debatable, because a $\$ 300,000,000$ case does not require 10 times the litigation expenses of a $\$ 30,000,000$ case. Still, because their fee awards are a decreasing function of settlement size, plaintiff's attorneys should be marginally less willing to invest time and money than defendants as the size of an action increases. This point is best illustrated by examining Figure $A$, infra text accompanying note 57. In Figure $A$, the $F$-curve is a direct function of the $S$-curve. If, however, the $F$-curve, at some point, rose at a slower rate than the $S$-curve, the attorney would want to settle sooner because the costs needed to generate an additional increment of fees would exceed those fees at an earlier point in time. See also infra note 78 and accompanying text (recommending that courts award attorneys a greater percentage of the recovery as recoveries increase).

53. The logic here is that defendants know that plaintiffs will sue at the point where plaintiffs' damages just exceed litigation costs. If defendants were to cross this threshold and cause additional damages, they would have to bear both the plaintiffs' damages (which, by this definition, approximately equal the plaintiffs' litigation expenses) as well as their own litigation costs. Thus, it is argued that as between these parties, defendants bear the total costs of increasing output beyond the litigation threshold, and they will predictably do so only if the gains to them exceed these social costs. Hence, there is no externality under this analysis because the social gains and costs remain in balance. Sce L. Kaplow, supra note 6, at 4-5. 
that the expected legal costs of an action are $\$ 500,000$ and consist exclusively of the cost of the attorney's time. If the victims are able to coordinate costlessly and secure counsel jointly, they will in theory sue once the damages exceed $\$ 500,000$, because only at that point would they obtain a net recovery. But if the plaintiff's attorney acts independently as a rational entrepreneur and anticipates that the court will award only twenty-five percent of the recovery as attorney's fees, then such an attorney would have little incentive to bring suit until the damages equal $\$ 2,000,000$, because only at that level would the attorney's payoff equal $\$ 500,000.54$ Contrary to the position taken by Menell, this analysis implies that defendants know ex ante that they need not restrict their output (and hence limit the damages caused thereby) to the level set by the plaintiffs' expected costs. Rather, defendants can increase their output (and damages) until the point at which the fraction of the damages recovered by the plaintiff's attorney equals the action's expected legal costs. The upshot of this analysis is that defendants may indeed impose an externality on society.

To this point, we have assumed unrealistically that (1) liability is certain if the requisite costs are expended, and (2) the attorney will not initiate suit until the damages exceed some minimum threshold level. Both of these assumptions need to be qualified. First, in the real world the outcome of litigation is seldom certain, and so the attorney must discount the probable fee award by both the risk of an adverse verdict and the time value of money during the period that the fee award is deferred. For example, if there was a fifty percent risk of a defendant's verdict in the foregoing illustration, the $\$ 2,000,000$ damage award would only produce an expected fee value of $\$ 250,000$. Hence, in theory, suit would not be justified from the attorney's perspective until the damages reached $\$ 4,000,000$, because only at that point would the "expected payoff" reach $\$ 500,000$.

Second, the attorney may well bring suit before damages reach a level that justifies a fee award equal to the attorney's expected opportunity cost, but will refuse to expend the time or money necessary to optimize the recovery and will settle the case prematurely. This tendency for premature settlement, which has been noted repeatedly in the literature about the economic effects of various fee award formulas, ${ }^{55}$ is

54. This example uses the $25 \%$ benchmark for fee awards common in securites class actions. See supra note 26 . In the antitrust context, however, where fee awards in class actions may be as low as $8 \%$, see supra note 51 , damages would in theory have to be 12 times greater than the fee award that would cause an attorney to undertake a suit, thus offsetting the deterrent effect of treble damages. Of course, the attorney has another option: namely, to undertake a suit, but not prosecute it vigorously, and then settle cheaply and prematurely in order to economize on opportunity costs. See infra notes 55-58 and accompanying text; Figure A, infra text accompanying note 57.

55. Professors Schwartz and Mitchell first advanced the argument that a percentage of the recovery fee formula creates an incentive for premature settlements. See Schwartz \& Mitchell, supra note 5, at 1 I36. Figure A is derived from a similar diagram 
best shown graphically. The shape of the $S$-curve on Figure A below assumes that litigation will usually be settled and that the size of the settlement will increase as a direct function of the attorney's time until a point is reached where further efforts produce little or no return. Assuming also that the plaintiff's attorney will be compensated on a percentage of the recovery basis (or that a court in applying any other fee formula will nevertheless tend to limit its fee award to some maximum percentage of the recovery), ${ }^{56}$ the $F$-curve on Figure A shows the fee award as a constant function of the settlement's size. Finally, the $O$-line shows the attorney's opportunity costs, which are assumed for the sake of simplicity to mount steadily over the period in proportion to the aggregate time expended by the attorney.

The utility of Figure $A$ is that it enables us to see how the interests of client and attorney diverge. Holding aside the impact of delay and the time value of money, the client is best off at point $X$, which is the point of greatest distance between the $F$-curve and the $S$-curve. In other words, if the client is paying the attorney only a percentage of each increment in the settlement's size, then it is in the client's interest to accept only the maximum possible settlement. Conversely, it is in the attorney's interest to settle much earlier at point $Y$, which is the point of greatest distance between the $F$-curve and the $O$-line. This distance represents the attorney's real economic profit from the action, and it is maximized at a point well before the client maximizes his return. Meanwhile, if we assume that only the client and the attorney have an interest in the action, the socially efficient settlement lies at point $Z$ between the attorney's and the client's optimum settlement positions. ${ }^{57}$ At point $Z$, which is the point of greatest distance between

used by Clermont and Currivan, who examined fee awards in class actions specifically. See Clermont \& Currivan, supra note 5, at 544 . It can be questioned whether the settlement's size increases in proportion to the time expended on the case by the plaintiff's attorney (as Figure A indicates), because the plaintiff's attorney's investment of time may provoke a counter-investment by the defendant. Yet, this assumption seems highly realistic within the context here considered where there is a pronounced cost differential favoring the plaintiffs and where, in this author's experience, defendants invariably test the plaintiff's attorney's seriousness before agreeing to settle.

56. In theory, a formula that awards fees based on attorney time expended, such as the lodestar formula, creates very different incentives. In applying the lodestar formula, however, courts generally reach results similar to those that obtain under the percentage of the recovery formula. See supra note 26.

57. An important distinction must be made between "efficiency" in its local and global senses. Point $Z$ is the efficient outcome only if we limit our attention to the interests of the immediate clients. This is generally an appropriate simplifying assumption, but it can be false if persons other than the plaintiffs benefit from the action. For example, an antitrust or securities class action may yield a general deterrent benefit that is proportionate to the settlement's size. Hence, if one fee formula encourages a larger gross recovery, it may be socially optimal because it discourages future law violations, even if it does not maximize the recovery to the clients. We need not pause, however, to consider this point further because this Article argues that the lodestar formula, which in theory should encourage the attorney to expend more effort on the action and thus 


\section{FIGURE A}

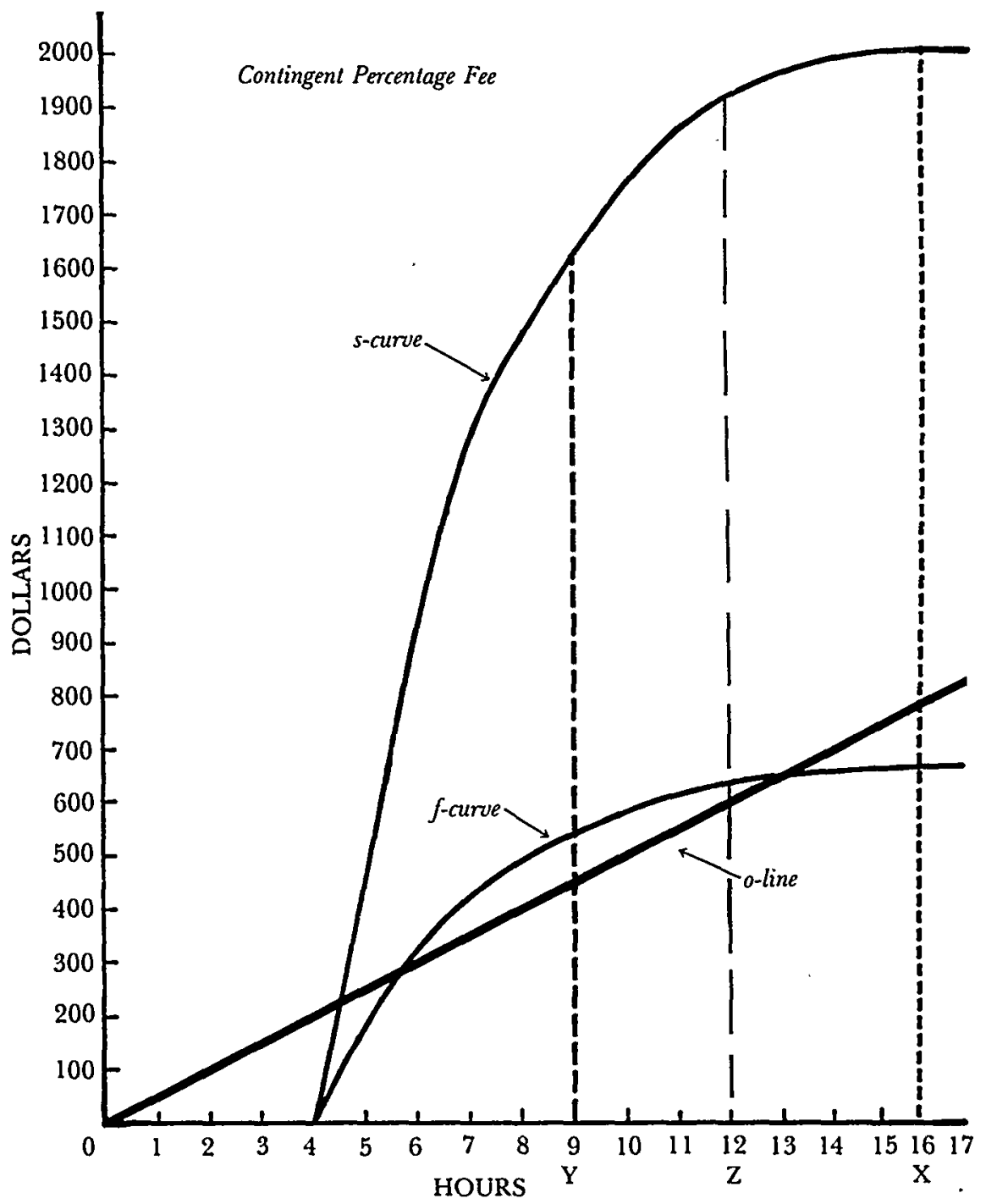

the $O$-line and the $S$-curve, the marginal costs of pursuing the action begin to exceed the marginal gains. That is, any further expenditure of effort will involve marginal costs greater than the marginal increment in the settlement's size and hence will normally result in social inefficiency (even if it is still in the client's interest to continue the action, because the client receives marginal gains but does not incur the marginal costs). This conclusion that the socially optimum settlement point is 
normally at point $Z$ is best understood if we think what would happen if the attorney and client were the same person. In that case, the attorney would focus on the total gains from settlement (that is, the sum of the client's gains and the attorney's gains), and these are maximized at the point of greatest vertical distance between the $O$-line and the $S$-curve (i.e., point $Z$ ).

This analysis has been used by others to explain the misincentives created by various fee award formulas and the difficulty of reaching the socially efficient outcome. Yet it also demonstrates that the attorney's incentive to litigate class actions may be inadequate from a social perspective, because the distance from point $Y$ to point $Z$ represents the shortfall in effort expended on the action below the level that would normally be considered socially optimal. ${ }^{58}$

Thus, we have encountered two related problems that arise when agency costs are significant. First, defendants have a greater incentive to invest in litigation than do plaintiff's attorneys, because the gains and losses of the two groups are asymmetric-that is, the plaintiff's attorney receives only a fraction of the defendants' losses. Second, plaintiff's attorneys have an incentive to settle prematurely and cheaply when they are compensated on the traditional percentage of the recovery basis. Sophisticated defendants can exploit these tendencies. Anticipating the plaintiff's attorney's lesser incentive to invest in the action, defendants can seek to "up the ante" by compelling their adversaries to incur litigation expenditures beyond the level at which the plaintiff's attorney can expect to profit. Dilatory tactics and discovery abuse by defendants thus become understandable as efforts to exploit their greater willingness to expend funds on the action. Furthermore, defendants need not actually make this investment if their greater willingness can be credibly signalled. Ex ante, the plaintiff's attorney should understand that the threat is credible and factor it into the settlement calculus.

\section{Policy Responses}

If Figure $A$ implies that private enforcement of law will be underfunded so long as the plaintiff's attorney is compensated on a per-

58. This assumes that there are no other beneficiaries of the action besides the plaintiff class. If there are, the social shortfall will be even greater. Should this incentive analysis be considered unrealistic, it is useful to examine the proposed settlement reached by the parties (over the objection of the Indian government) in the Bhopal disaster class action brought against Union Carbide Corporation. While the plaintiff's attorneys agreed to settle for $\$ 350,000,000$, legal and financial analysts had expected a settlement "in the $\$ 600$ million range." Diamond, $\$ 350$ Million Pact Reported in Suits over Bhopal Leak, N.Y. Times, Mar. 23, 1986, at 1, col.4. Arguably, this is an example of premature settlement. Alternatively, it may be an instance where the instability and internal strife within the plaintiffs" "ad hoc" law firm made protracted litigation infeasible. See Meier, Legal Tussle: Lawyers for Victims of Bhopal Gas Leak Fight One Another, Wall St. J., May 1, 1986, at 1, col. 6; infra note 115 . 
centage of the recovery basis, what policy responses are appropriate? One answer might be to employ the lodestar formula, which essentially compensates plaintiff's attorneys for their time at their normal billing rates. ${ }^{59}$ ln fact, however, the lodestar formula may exacerbate the problem of cheap settlements. By severing the fee award from the settlement's size, this formula facilitates the ability of defendants and the plaintiff's attorneys to arrange collusive settlements that exchange a low recovery for a high fee award. ${ }^{60}$ In addition, the lodestar formula essentially places the court in the position of a public utility commission that regulates the "fair" return the attorney receives by both determining the attorney's normal billing rate and assessing whether the attorney's time was reasonably expended. ${ }^{61}$ At a minimum, such an undertaking imposes a substantial burden on the already overloaded judicial system, thus increasing the earlier noted disparity between the social and private costs of litigation. ${ }^{62}$

In light of the lodestar formula's deficiencies, it is worth asking what other alternatives can be imagined. An economic answer might be to eliminate the principal-agent relationship entirely by permitting the plaintiff's attorney to acquire all the client's rights in the action. ${ }^{63}$ The beauty of this approach is that the attorney is given the incentive to expend effort up to the socially optimal position at point $Z$, where marginal costs equal marginal revenues. In principle, this solution could

59. A fee award based on the lodestar formula may also include a contingency bonus so as to reflect the risk assumed, the deferral of payment, and certain other factors. But see Blum v. Stenson, 465 U.S. 886, 897 (1984) (indicating that such an award is rarely appropriate). For a fuller description of the lodestar formula and the difficulties associated with awarding contingency bonuses, see Leubsdorf, supra note 15 , at 478-501.

60. For a discussion of the incentives that arise for a collusive settlement once the size of the fee award can be divorced from the settlement's size, see infra notes 130-132 and accompanying text.

61. The author has made this argument at greater length elsewhere. See Coffee, Plaintiff as Monitor, supra note 5, at 38-40. Recent cases have greatly increased both the findings of fact that must be made and the paperwork that must be filed with, and reviewed by, a court before a fee award order can be entered that will withstand appeal. See New York State Ass'n for Retarded Children, Inc. v. Carey, 711 F.2d 1136, 1147-48 (2d Cir. 1983); Gagne v. Maher, 594 F.2d 336, 345 (2d Cir. 1979), aff'd, 448 U.S. 122 (1980); In re "Agent Orange" Prod. Liab. Litig., 611 F. Supp. 1296 (E.D.N.Y. 1985).

62. For example, in the Fine Paper antitrust litigation, the district court spent 41 hearing days reviewing the fee petitions and considering challenges to them. Thereafter, the court wrote a lengthy opinion of over 100 pages. See Coffee, Private Attorney General, supra note 5 , at 255 n.94. But the Third Circuit partially reversed the district court, thus requiring even further litigation. See In re Fine Paper Antitrust Litig., 98 F.R.D. 48 (E.D. Pa. 1983), rev'd in part, 751 F.2d 562 (3d Cir. 1984). When the fee petition hearing consumes nearly as much judicial time as the litigation of the substantive merits, it appears that the tail has begun to wag the dog. Such a case well illustrates Professor Shavell's thesis that litigation receives a public subsidy. See Shavell, supra note 6 .

63. Professor Scott concludes that for the "most effective enforcement, the recovery in its entirety should go to the attorney . . . Scott, supra note 28, at 941 n.43. 
be implemented by designing a competitive auction procedure under which attorneys would bid for all the rights in an action, with the winning bidder's payment going to the victims in return for an assignment of their legal rights.

Unfortunately, this proposal would also eliminate the incentive for attorneys to incur search costs and detect legal violations in the first instance. The entrepreneurially motivated attorney who suspects that a legal violation has occurred would have a reduced incentive to investigate further because, even if a violation is discovered, the attorney would still have to outbid others in order to profit from this effort. In effect, such an attorney would be in the position of a prospector who cannot stake out a claim or an inventor who cannot patent an invention. Denied such a property right, the attorney would have little incentive to incur costs or accept risk.

If we were to respond to this problem by adopting a legal rule that conferred all rights in an action to the first party to file, then an incentive to search would certainly be created. However, the rule would do so at the cost of minimizing compensation to the victims because there would be no competitive bidding for the property right. In addition, races to the courthouse and underresearched, hastily pleaded actions would be encouraged.

Still another variation on this approach might be to accord plaintiff's attorneys a different kind of property right by selling them a franchise to monitor a given area, however defined, for violations of law. ${ }^{64}$ This system creates an incentive to search, but it also gives rise to a host of other problems. Because such a franchise right would have to be sold before legal violations were discovered (or arose), meaningful compensation could not be awarded. Neither the number of victims nor violations could be known in advance, and without such information, compensation is impossible.

Of course, compensation is not necessary (or at least is of secondary importance) if potential wrongdoers can be adequately deterred. This argument suggests that a franchise auction model should at least be considered in those areas where deterrence appears to be the law's primary objective. There is, however, a further problem with the idea of a franchise auction that detracts from its deterrent capacity. The strength of private enforcement is that it supplements the enforcement resources of the state by creating incentives for a potentially unlimited number of enforcers to enter the field and search out violations of law. Once a monopoly is accorded to a private enforcer, however, there would be a reduction in aggregate enforcement output because a monopoly inherently produces lower output than a competitive market

64. The idea of franchise bidding has been more generally discussed in the economic literature. See, e.g., Williamson, Franchise Bidding for Natural Monopolies-In General and With Respect to CATV, 7 Bell J. Econ. 73 (1976). 
equilibrium. ${ }^{65}$ In addition, the prospects for collusion would be aggravated because defendants themselves might bid at the auction through covert agents for the role of exclusive private enforcer. Alternatively, defendants could seek to bribe the holder of such a private enforcement franchise. Such tactics would not force the defendant to internalize the appropriate level of costs because the private attorney general who purchased the franchise would not accurately know the level of output or damages that the defendant intended to produce at the time of the bribe.

Given that this auction approach seems unpromising, other less perfect methods of alleviating the externality caused by the principalagent problem must be examined. It is at this point of searching for "second best" solutions that we reencounter the contemporary debate over treble damages. In effect, multiple damages can be defended as a crude approximation of the optimal solution. If the fee recovery tends to be a fairly stable fraction of the total recovery, then the case for multiple damages is that they can place plaintiff's attorneys in the same position as their clients would have been in if the clients were making the litigation decisions in a suit for simple compensatory damages. Put differently, once the attorney's expected recovery equals the victim's actual damages, the Menell suit preclusion equilibrium is restored. ${ }^{66}$ To illustrate, if the plaintiff's attorney were awarded one-third of the recovery and the damages were trebled, the attorney would receive the equivalent of the plaintiff's compensatory damages. This should cause the attorney to act in the same manner as an individual client in a nonclass action where the client wished to recover compensatory damages. In theory, the level of investment in the action should not differ, and attorney and client should respond similarly to identical settlement offers.

The suit preclusion equilibrium under a multiple damages formula, however, generates considerably more deterrence than the

65. To the extent that a monopoly reduces enforcement output, the auction solution reduces the tendency for overenforcement that may arguably result because the optimum penalty, to be effective, must exceed the social loss in order to compensate for the uncertainty of apprehension and conviction. See Landes \& Posner, supra note 6 , at 22-23. But see Polinsky, Private Versus Public Enforcement of Fines, 9 J. Legal Stud. 105,108 (1980) (monopoly may result in more or less enforcement than competitive markets depending upon relative enforcement costs). However, in this author's view, two other factors make the "overenforcement thesis" unrealistic in the context of class and derivative actions. First, "asymmetric stakes" can lead to underenforcement, see supra notes 49-54 and accompanying text, and thus offset to an indeterminate extent the overinvestment that the "excessive" penalty attracts. Second, private enforcers have tended to minimize search costs by piggybacking on public enforcement actions, such as those brought by the SEC and the antitrust agencies. See supra notes 36-37 and accompanying text. Hence, "overenforcement" at the private level results only if there is first "excessive" enforcement at the public level. No evidence suggests that public overenforcement is currently a problem.

66 . See supra notes $45-46,53$ and accompanying text. 
compensatory damages equilibrium. From the perspective of Menell and Kaplow, multiple damages can be said to overdeter because they cause defendants to restrain their output even when further production would produce gains in excess of social costs. ${ }^{67}$ On the other hand, this additional deterrent may be thought desirable as a means of offsetting the low risk of detection that accompanies many forms of illegal behavior. 68

Recently, some economists have criticized the treble damages formula on the ground that it produces excessive investment in an action. They have therefore suggested that treble damage awards be "decoupled" so that, for example, plaintiffs would receive single damages, but defendants would pay treble damages, and the difference would go to the government as a civil penalty. ${ }^{69}$ In reality, our system of private enforcement in class actions is already "decoupled" (and more so) because the plaintiff's attorney, who in fact determines the level of investment in an action, receives considerably less than even single damages. ${ }^{70}$ Thus, the fault of the "decoupling" proposal is not its focus on the incentives that fuel litigation, but rather its overly facile

67. That is, if a defendant creates more gain for itself than the sum of the compensatory loss to the plaintiffs plus the litigation expenses of both sides, the social gains exceed the social costs. From an economic standpoint, one does not want to deter sucli a defendant from producing additional output. Yet a private incentive to sue remains because the treble damage penalty creates a private gain to the plaintiff that is not matched by any social gain. Of course, a similar argument could also be used to justify theft if the thief puts the stolen asset to a higher valued use so that the thief's gains exceed the victim's loss plus any litigation expenses. Nonetheless, important personal rights are not typically at stake in antitrust, securities, and derivative litigation, and thus one may be more concerned about the risks of overdeterrence in these contexts, particularly where the underlying misbehavior amounts only to negligence.

68. The standard economic theory of deterrence defines the expected penalty cost as the likely penalty discounted by the risk of apprehension and conviction. Hence, for penalties to work, they must normally exceed the social loss if we assume that the probability of apprehension falls below $100 \%$. See Becker, Crime and Punishment: An Economic Approach, 76 J. Pol. Econ. 169, 179-81 (1968).

69. See Schwartz, An Overview of the Economics of Antitrust Enforcement, 68 Geo. L.J. 1075, 1093-95 (1980); cf. A. Polinsky, Detrebling Versus Decoupling Antitrust Damages: Lessons from the Theory of Enforcement 6-8 (Working Paper No. 25, Law and Economics Program, Stanford Law School, Jan. 1986) (analysis of "decoupling" proposals). Professors Steven Salop and Lawrence White, both economists, have recently argued that treble damages produce excessive litigation: " '[B]y leading to more costly and lengthy litigation, the higher damages multiple may largely benefit the lawyers and experts involved in the litigation at the expense of the parties to the dispute." " Moore, Antitrust Project Provides Little Ammo for Damage Repeal, Legal Times, Nov. 4, 1985, 1 col. 2, at 24, col. 4 (quoting the Salop \& White paper). While treble damages do invite greater expenditures by plaintiffs, Salop and White's conclusion is questionable. Their implicit assumption is that we start with a level playing field which treble damages disrupts. The alternative perspective is that the asymmetric stakes in class actions create an imbalance which multiple damages offset (whether insufficiently or excessively). See supra notes 51-54,66 and accompanying text.

70. See supra note 51 (fee award in MDL antitrust class actions averaged $8.3 \%$ of the recovery). 
assumption that clients determine the level of investment in an action. Once we recognize that a substantial principal-agent problem is inherent in class and derivative actions, treble damages can be seen as a corrective measure that offsets the tendency of both the percentage of the recovery fee formula and asymmetric litigation stakes to produce underfunding. To be sure, no damages formula can be described as optimal, but one cannot characterize the incentive to litigate under a treble damages formula as "excessive" until one more accurately defines the level of investment in the action that would otherwise result.

In this same light, not requiring litigants to bear the public costs of an action can also be seen as a "second best" solution by which society unconsciously compensates for the inadequate incentive to litigate faced by entrepreneurially motivated attorneys. Although others may view this subsidy as tending to create an excessive incentive to litigate, ${ }^{71}$ a public subsidy may be justifiable if we start from the premise that plaintiff's attorneys see a much smaller payoff from litigation than do their clients. The investment that attorneys make in an action in the form of litigation expenses must earn a competitive return. If it does not, then attorneys are better off investing in some other risky asset. As a result, the entrepreneurial attorney will not advance additional litigation expenses unless he expects the fee award to pay a competitive return on them and also cover the attorney's opportunity costs. ${ }^{72}$ Hence, requiring the plaintiff's attorney to bear some portion of the public costs would aggravate the underfunding of litigation precisely in those areas where potential clients cannot effectively coordinate to choose and monitor their attorney.

Other "rough justice" solutions are also possible. For example, courts could increase their level of fee awards to plaintiff's attorneys (for instance, from twenty-five to fifty percent). In terms of the Menell suit preclusion equilibrium, higher fee awards would encourge plain-

71. See Shavell, supra note 6, at 333,339. Although Professor Shavell would describe this subsidy as an externality, he recognizes that no systematic relationship exists between the social and private benefits of litigation. Thus, under his analysis, the public subsidy may sometimes produce a social benefit. In contrast, using this Article's analysis, it is indeterminate whether the subsidy exceeds, offsets, or fails to counter the impact of the principal-agent problem and asymmetric stakes.

72. To earn a fee award in class and derivative litigation, the plaintiff's attorney must fund the action through settlement or judgment hecause, in a class action, the lead plaintiff usually has only a nominal stake in the action. Uniquely, American law permits the plaintiff's attorney to advance litigation expenses on a contingent basis (meaning that the attorney bears the risk of losing these expenses if the action is unsuccessful). See supra note 24 and accompanying text. As a result, an attorney's willingness to advance litigation expenses will be constrained by the knowledge that their repayment depends on the action's success (and to a lesser degree on the court's willingness to view the expenses in question as reasonable and allowable). This knowledge also induces the attorney toward an early settlement because, as a rational entrepreneur, the attorney will not invest funds in a risky investment if it offers a lower rate of return than is available in other markets. 
tiff's attorneys to undertake suit at an earlier threshold-one closer to the point where the victim's damages equal the defendant's gain. While this approach reduces compensation to the victims, it correspondingly increases the incentive to search, thereby generating more deterrence and ultimately reducing the prospect of future injury.

If there is then an arguable case for higher fee awards, ${ }^{73}$ what benchmark should be used? In strict theory, if liability were certain, a rational plaintiff would be willing to pay up to ninety-nine cents to recover a dollar of damages. Yet in practice, courts will seldom award plaintiff's attorneys much more than thirty percent of the recovery in "common fund" cases. ${ }^{74}$ The net result is to deny plaintiffs in class actions the ability that individual plaintiffs possess to strike expensive, but rational, bargains for private enforcement services. As a result, this limitation invites defendants to increase their injury-causing behavior beyond the suit preclusion equilibrium postulated by Menell, so that their behavior's social costs can exceed its gains. ${ }^{75}$

Given the obvious externality that can result from the use of such parsimonious judicial fee award standards, what policy is preferable? Clearly, it is too simple to answer that courts should award a higher percentage of the recovery, because that prescription is open ended. A more sensible response might be to apply the standard prescription of neoclassical economics that the "law should mimic the market." In the class action context, that would mean attempting to award the fee that informed private bargaining, if it were truly possible, might have reached. The simplest way for the law to duplicate the bargain that informed parties would reach if agency costs were low is to look to fee award levels in actions brought by sophisticated private parties under the same or comparable statutes. For example, the Georgetown study of antitrust enforcement found that the fees awarded in large class actions averaged $8.3 \%$, but rose to $20.2 \%$ in non-class action cases. ${ }^{76}$ This latter context might serve as the appropriate proxy to which courts should look when setting fees in antitrust class actions, where private negotiation among informed parties is impossible. ${ }^{77}$ To be sure, a vari-

73. Of course, the case for higher fee awards exists only to the extent that a litigation's social costs do not exceed its social benefits. In some types of tort litigation, such as malpractice actions against doctors and "due care" actions against corporate directors, reasonable persons can disagree as to whether social costs exceed social benefits. To reduce socially inefficient litigation, however, substantive law reforms should be made. Reform of the procedural law, including fee award formulas, should attempt only the less complicated goal of reducing agency costs.

74. See supra notes $26,5 \mathrm{I}$.

75. See supra notes $49-54$ and accompanying text.

76. See supra note $5 \mathrm{I}$.

77. After determining the fee award percentage in the most comparable area of private litigation, courts should also adjust that percentage upward to compensate the class action plaintiff's attorney for assuming the additional risk associated with a contingent fee payment arrangement. 
ety of factors distinguish class actions from private suits. For example, in class actions, the plaintiff's attorney typically assumes more risk because the fee award is contingent, but may also have lower search costs (if the attorney is piggybacking on a prior governmental action). Still, if courts were to ask what fee structure an informed, sophisticated client would use to compensate his attorney when close monitoring is not feasible, they would at least have focused on the correct question. Moreover, the preceding analysis suggests that the most logical answer to this problem of premature settlement would be to base fees on a graduated, increasing percentage of the recovery formula-one that operates, much like the Internal Revenue Code, to award the plaintiff's attorney a marginally greater percentage of each defined increment of the recovery. ${ }^{78}$ While this approach cannot be said to eliminate the inevitable tension between the interests of plaintiff's attorneys and their clients in class actions, it can at least partially counteract the tendency for premature settlements.

Principal-agent problems will persist, however, and their existence implies that there can be no socially optimal suit preclusion equilibrium as postulated by Menell. Either society risks overdeterring the defendant through multiple damage formulas, or it accepts the likelihood that class and derivative litigation will be underfunded. ${ }^{79}$ On a practical level, some measures may increase the plaintiff's ability to monitor

78. In terms of Figure $A$, an increasing percentage of the recovery formula tends to offset the incentive for attorneys to settle prematurely at point $Y$ and moves them toward the socially optimal position, point $Z$. See supra notes $56-58$ and accompanying text. Under a graduated percentage of the recovery formula, an attorney might be awarded $20 \%$ of the first million dollars of recovery, $25 \%$ of the second million dollars of recovery, and $30 \%$ of amounts in excess of $\$ 2,000,000$. The author is aware of one recent instance where a stockholders' protective committee negotiated such a scheme with its plaintiff's attorney, thus suggesting that informed parties might employ an increasing percentage formula in a class action if private bargaining were feasible. Note, however, that this proposal is exactly the opposite of the Reagan administration's proposed legislation to reduce contingent fees as a percentage of the recovery. See supra note 18.

79. Because it is not possible to specify the level of costs that generally must be incurred by plaintiffs, no claim is here made that the plaintiff's side will always be underfunded. The conventional wisdom is that litigation costs tend to be lower for plaintiffs than defendants. This cost differential may counteract the fact that defendants have a greater stake in litigation than plaintiff's attorneys, and may render indeterminate the issue of which side has the greater willingness to fund an action. See infra notes 93-97 and accompanying text. In some areas, the substantive law makes it fairly simple for the plaintiff to prove a prima facie case, rendering less important the existence of asymmetric litigation stakes. For example, some actions under the federal securities laws (such as a suit under $\S 11$ of the Securities Act of 1933, 15 U.S.C. $\S 77 \mathrm{k}$ (1982)) do not require that plaintiffs prove scienter, causation, or reliance. See R. Jennings \& H. Marsh, Securities Regulation 753-58 (5th ed. 1982). However, factors later assessed, including the general unavailability of equity investments in plaintiff's litigation, see Model Rules of Professional Conduct Rule 1.8(j) (1983), and the small size of plaintiff's firms, see infra notes 102-115 and accompanying text, point toward such a tendency. Thus, even if there is a cost differential favoring the plaintiff's side, the defendant can still attempt to 
their attorneys, ${ }^{80}$ but the most feasible answer to the attorney's inadequate incentive to fund litigation probably involves some combination of multiple damages, an increasing percentage of the recovery formula, and higher fee awards. Although such a policy is clearly feasible, it brings us back to the predictable response that enhancing the plaintiff's attorney's incentive may also invite extortion and "strike suits." Parts II and III assess these topics.

\section{Strike Suits: Theory, Evidence, ANd InfERence}

The one persistent empirical observation about shareholder litigation is that it results in very few litigated victories for plaintiffs. During the I940s, a study for the New York State Chamber of Commerce found that only thirteen out of 573 derivative actions involving publicly held corporations resulted in judgments for plaintiffs. ${ }^{81}$ This finding prompted New York to adopt legislation requiring that the plaintiff in a derivative action post a security for expenses bond to cover the defendant's expenses. ${ }^{82} \mathrm{~A}$ more recent eight-year study of both securities class actions and derivative suits reported that plaintiffs were victorious in less than one percent of all verdicts. Defendants obtained a dismissal (on either procedural or substantive grounds) or judgment in roughly twenty-five percent of the cases; the remainder of the cases were settled. ${ }^{83}$ Although critics may read this evidence as implying that derivative actions seldom raise meritorious claims, this interpretation does not explain why the same pattern also prevails outside the context of shareholder litigation and seems to characterize other areas of class action litigation as well. A study by William Baxter found that plaintiffs in

force the plaintiff's attorney to invest more than is economically rational in a risky investment which has a smaller payoff to the plaintiff's attorney than to the defendant.

80. For example, in class and derivative actions, a number of federal courts prohibit contemporaneous negotiation of the settlement and the plaintiff's attorney's fee award. See Prandini v. National Tea Co., 557 F.2d 1015, 1021 (3d Cir. 1977); American Law Institute, supra note 1 , at 232-33, 242.

81. See F. Wood, supra note 10 , at 32 . This survey covered all derivative lawsuits filed between 1932 and 1942 in several New York state and federal courts. Wood's bias was not hidden; he concluded that plaintiff's attorneys in this field made "the ambulance-chaser by comparison a paragon of propriety." 1d. at 47. For an analysis and review of his findings, see Garth, Nagel \& Plager, supra note 22, at 142-43.

82. See N.Y. Bus. Corp. Law $§ 627$ (McKinney 1965 \& Supp. 1986). For a general review of these statutes and the movement that led to their codification, see Hornstein, The Death Knell of Stockholders' Derivative Suits in New York, 32 Calif. L. Rev. 123 (1944).

83. See Jones, An Empirical Examination of the Resolution of Shareholder Derivative and Class Action Lawsuits, 60 B.U.L. Rev. 542, 544-45 (1980). Professor Jones' study covered 205 publicly traded corporations and followed some 348 shareholder derivative and class action suits. Only two of the 88 cases that were litigated to judgment resulted in judgment for the plaintiffs. 1d. at 545. Before we dismiss the value of this form of litigation, however, the observation must be made that over $75 \%$ of these suits produced some form of settlement. Id. For a critical reanalysis of this data, see Garth, Nagel \& Plager, supra note 22, at 145-47. 
private antitrust actions were successful only $15.2 \%$ of the time between 1964 and $1970 .{ }^{84}$ In sharp contrast, between 1890 and 1969, the Department of Justice and the Federal Trade Commission experienced success rates in antitrust litigation of seventy-four and seventy-five percent, respectively. ${ }^{85}$ Because private antitrust actions during this period typically piggybacked on prior governmental actions, ${ }^{86}$ and thus involved the same allegations, it is difficult to believe that a substantial difference in legal meritoriousness distinguishes these private and public actions.

Initially, this pattern of a very low rate of plaintiff victories seems anomalous because a widely accepted economic model of litigation predicts that trials in civil actions should normally produce a fifty percent victory rate for each side. ${ }^{87}$ This "optimism model" starts from the premise that the parties, because they wish to minimize litigation costs, will settle any action if they can agree on the litigation odds. ${ }^{88}$ Indeed, it is in the interest of each side to reveal favorable evidence or arguments to the other so that a mutual perception of the litigation odds will produce a settlement and avert unnecessary costs. Trials therefore occur only when the parties are unable to agree on the litigation odds, meaning that one side is unduly "optimistic." This excess optimism is a random factor that should divide equally between plaintiffs and defendants. Professors Priest and Klein have amassed considerable evidence that appears to support this model by showing that an approximately fifty percent victory rate has characterized many different kinds of litigation. ${ }^{89}$

84. See The Political Economy of Antitrust: Principal Paper by William Baxter 17, table I-1 (R. Tollison ed. 1980); see also Priest \& Klein, supra note 19, at 52-53 (comparing success rates in antitrust litigation between private and public plaintiffs). A study by Professors Salop and White, in connection with the recent Georgetown University project on antitrust enforcement, reported a less than $30 \%$ victory rate for plaintiffs out of a very small number of cases reaching a litigated final judgment. See S. Salop \& L. White, supra note 51 , at $11-12,66$.

85. See Posner, A Statistical Study of Antitrust Enforcement, 13 J.L. \& Econ. 365, 384 , table $14(1970)$. Where the goverument is the plaintiff, very different considerations apply, some believe, because bureaucratic agencies may not pursue cases with marginal prospects for success at trial. See Priest \& Klein, supra note 19, at 53-54.

86. As part of the Georgetown University antitrust enforcement project, Professors Kauper and Snyder found that between 1976 and 1983, the percentage of "follow on" cases declined. Prior to 1960 , another study found that the percentage was approximately $75 \%$ of all treble damages actions. See Moore, supra note 36 , at 24 , col. 3 . The period exmained by Baxter, see supra note 84 and accompanying text, falls roughly in between the periods analyzed by these two studies.

87. See Priest \& Klein, supra note 19, at 3-5.

88. This view that trials result from excess optimism on one side was first expressed by Professor Gould. See Gould, supra note 19, at 286. It was further expanded and formalized by Professor (now Judge) Posner. See R. Posner, Economic Analysis of Law 434-40 (2d ed. 1977).

89. Priest and Klein provide data on the percentage of plaintiff verdicts in jury trials in Cook County, Illinois, broken down into generic categories such as auto collision, 
However, the optimism model recognizes one exception to the prediction that litigated cases should divide equally between plaintiff and defendant victories. When one side has more at stake than the other, this model predicts that the outcome of litigated decisions should tilt in favor of the side having more at risk.90 The logic of this "asymmetric stakes" exception to the general rule of an equal victory rate is that a defendant with more to lose than the plaintiff will proceed to trial only in cases where the litigation odds are strongly in the defendant's favor. Hence, when defendants have more to lose than the plaintiff's attorney has to gain, the cases that go to trial should be disproportionately populated with overly optimistic plaintiffs and produce relatively few plaintiff victories. ${ }^{91}$

In this light, the key fact that has been overlooked about class and derivative actions is that they inherently involve asymmetric stakes. That is, to the extent that a principal-agent problem enables plaintiff's attorneys to act in their own self-interest, their incentive to litigate depends upon the expected fee recovery rather than the expected damage

product liability, and the like. They found the aggregate percentage of plaintiff's verdicts to be $48.47 \%$ over 14,671 cases. See Priest \& Klein, supra note 19, at 31-41. For a critique of their work, see Wittman, 1s the Selection of Cases for Trial Biased?, $14 \mathrm{~J}$. Legal Stud. 185 (1985). For still more data supporting the optimism model, see Priest, Reexamining the Selection Hypothesis: Learning from Wittman's Mistakes, 14 J. Legal Stud. 215 (1985).

90. See Priest \& Klein, supra note 19, at 25.

91. A good argument exists that the significance of the asymmetric stakes exception is far greater than Professors Priest and Klein have recognized. This is because some of the plaintiff victories they count on one side of their $50: 50$ victory ratio probably belong on the other. For example, suppose a plaintiff sues for $\$ 5,000,000$, declines a $\$ 2,000,000$ settlement offer, and obtains a trial verdict of only $\$ 1,000,000$. Officially, this would be recorded as a plaintiff's victory. In reality, such a victory is illusory because the real dispute was over damages, not liability. Defendant verdicts are less ambignous because they result in either no liability or no damages. Priest and Klein recognize that litigation consists of both liability disputes and damage disputes, but assert that in both contexts, the parties should settle on the basis of the litigation odds in order to minimize litigation costs. See Priest \& Klein, supra note 19, at 29-30; Priest, supra note 89 , at 216-19. Although their analysis seems correct, it does not respond to the implications of their data. That is, the $50 \%$ rate of plaintiff victories in litigated cases needs to be discounted by the number of illusory victories in damage disputes where defendants actually prevail. This is necesssary even if damage disputes divide on a 50 . 50 basis, because at present Priest and Klein record all damage disputes as plaintiff victories. Once this subtraction is made, the apparent $50 \%$ victory rate in litigated cases necessarily tips in favor of defendants. In turn, this supports an inference that plaintiffs behave "as if" they are excessively optimistic. Although this conclusion would not challenge the central contention of Priest and Klein that the selection of cases for trial is biased, it does suggest that asymmetric stakes may be present in a far higher percentage of cases than their analysis would indicate. Rather than the exception, asymmetric stakes may be closer to the norm, and may predominate wherever weak client control gives attorneys the real decision-making power. Client control may be weak in many areas of law, thereby causing the settlement calculus to be influenced by the lawyer's focus on the fee award rather than the recovery. See D. Rosenthal, Lawyer and Client: Who's In Charge? 106-15 (1974). 
recovery. As earlier noted, the fee award has traditionally ranged between twenty and thirty percent of the damage recovery in most class and derivative actions, and the percentage declines as the damages increase. ${ }^{92}$ Thus, the stakes are inevitably asymmetric, because the plaintiff's attorney can only gain in fees a fraction of what the defendants can lose in damages. Indeed, even if high agency costs did not apply to the attorney-client relationship, there would be some contexts in which the stakes would remain asymmetric. An example is the derivative action, where the recovery goes not to the shareholder plaintiff, but to the corporation. Hence, the actual plaintiffs benefit only to the extent of their pro rata interest in the corporation. The low incidence of litigated plaintiff's victories in class and derivative actions seems to be less evidence of extortion by plaintiffs than it is corroboration of the asymmetric stakes exception to the optimism model. To be sure, the cases actually litigated might appear to be disproportionately composed of actions that have little merit, but there is no reason to suppose that these cases are representative of the broader range of class and derivative actions that are settled. Rather, the sample of litigated cases is an inherently biased one.

\section{The Plaintiff's Attorney's Incentives: Toward AN ECONOMIC MODEL}

The ability of the optimism model to explain the outcomes of litigated actions does not itself refute the possibility that class and derivative actions tend to be disproportionately nonmeritorious. Both theories-the asymmetric stakes explanation and the claim that these actions are brought for extortionate motives-could be partially correct. This Part therefore examines four different explanations of why a rational plaintiff's attorney would bring an action having little probability of success at trial. This analysis then sets the stage for a discussion of what reforms, if any, are justified.

\section{A. The Cost Differential Explanation}

Professors Rosenberg and Shavell have explained the nuisance action in terms of a cost differential that may exist between plaintiffs and defendants. ${ }^{93}$ When it is costlier for defendants to litigate than plaintiffs, even a frivolous action may possess some settlement value because obtaining the dismissal of such an action, they argue, imposes more costs on defendants than plaintiffs. Essentially, plaintiffs know that they can impose substantially greater litigation expenses on defendants than the plaintiffs will incur themselves. As a result, they can extort some form of payment (typically in the form of a fee award) as the price for

92. See supra note 26 . A somewhat lower fee award percentage may apply in antitrust actions. See supra note 51 .

93. See Rosenberg \& Shavell, supra note 8 , at 4-5, 9-10. 
not subjecting defendants to this greater expense. A number of factors give this scenario some plausibility: the extreme difficulty of obtaining dismissal on the pleadings; the costly nature of the discovery process for defendants, who must respond to voluminous discovery requests that plaintiffs can make cheaply; the need for multiple attorneys to represent the different defendants in a derivative action; and the plaintiff's attorney's typically lower overhead costs. In combination, these factors create a significant cost differential that favors plaintiffs and may give a case settlement value largely unrelated to its litigation odds. ${ }^{94}$ Indeed, a plaintiff's attorney with low opportunity costs could create a cost differential by suing multiple defendants (such as corporate directors in a derivative action, or the accountants, underwriters, and secondary participants in a securities class action) whose collective time carries a high opportunity cost.

Still, the existence of a cost differential favoring the plaintiff does not necessarily imply that the case will be settled on terms more favorable than the litigation odds would dictate. If the defendant officers and directors in a derivative suit or securities class action view themselves as "repeat players," they may believe that yielding to extortion in this fashion will only expose them to future litigation. Hence, they may behave strategically and insist on going to trial. In addition, to the extent that defendants either see reputational injury in a settlement or expect their litigation expenses to be fully indemnified by the corporation, these defendants will not be much affected by the cost differential that favors the plaintiffs. Indeed, even if these defendants are prone to extortion because they are not true "repeat players," the insurance company that issued the directors and officers insurance policy covering the defendants might resist a settlement because the insurer is a repeat player. As a result, the outcome is indeterminate. Cases having a low probability of success at trial may sometimes be settled for amounts that reflect more than the litigation odds, but it is far less certain that pure extortion will work unless the defendants believe they have no further exposure to frivolous litigation. ${ }^{95}$

94. According to data compiled by The Wyatt Company, an insurance consulting firm, the average cost of defending a claim made against corporate directors was $\$ 461,000$ in 1984. See Schatz, Focus on Corporate Boards: Directors Feel the Legal Heat, N.Y. Times, Dec. 15, 1985, at F12, col. 2. 1t is highly doubtful that plaintiffs spend (or could spend) even a substantial fraction of this amount on a per action basis. If, for example, an investment of $\$ 100,000$ in time and effort by plaintiffs would cause the defendants to expend $\$ 461,000$, then this cost differential favoring plaintiffs lends support to the Rosenberg and Shavell thesis that extortion is possible. On the other hand, one must know the relative breakdown of this $\$ 461,000$ figure between plaintiff and defendant expenses (both of which may be paid out of insurance proceeds in a settlement) to know if the cost differential outweighs the countervailing force of the asymmetric litigation stakes factor.

95. This analysis suggests that directors who are about to retire or resign, or who are serving a target corporation that is scheduled to disappear in a merger or takeover, may be more willing to settle. 
Professors Rosenberg and Shavell appear to have looked at only one side of the coin in attempting to rest their theory of nuisance actions on the cost differential that tends to favor plaintiffs. One countervailing factor that inherently favors defendants is the time value of money, which may be a far more important factor than the cost differential. To the extent that the defendants can procrastinate, the present value of the plaintiff's expected settlement declines. In principle, the defendants' gain from procrastination equals the plaintiffs' loss because settlements are simply transfer payments from the former to the latter. In reality, matters may be more complex because procrastination requires the expenditure of litigation cost. Still, at a realistic discount rate, plaintiff's attorneys may lose more because of deferral than defendants must spend to achieve delay. If so, this factor would be known to both sides in advance and might produce bluffing behavior in the form of dilatory tactics by the defendants that ultimately reduce settlements.

Overshadowing the effect of the time value of money is a more basic problem with the cost differential explanation that involves the now familiar concept of asymmetric stakes. Put simply, the cost differential may be more than offset by a benefit differential that both favors defendants and tends to decrease the value of an action to the private enforcer. Indeed, even a two-to-one cost differential favoring the plaintiff will be offset by the fact that the plaintiff's attorney's fee award tends to be no more than twenty to thirty percent of the total settlement. To illustrate, suppose that it would cost the defendants $\$ 200,000$ to prepare for trial while the plaintiff's side need spend only $\$ 100,000$. Holding aside the action's possible merit, the maximum the defendants would pay to avoid this expenditure is something less than $\$ 200,000$. Yet even from a $\$ 200,000$ settlement, the plaintiff's attorney would receive only $\$ 40,000$ to $\$ 60,000$-a fee award that may not cover his own opportunity costs, particularly if the defendants' dilatory conduct compells the plaintiff's attorney to expend more time on the action than he anticipated. This is a curious form of extortion when the plaintiff's attorney's threat, if carried out, could cause him more harm than the defendants. Of course, if a collusive settlement can be arranged between the plaintiff's attorney and the defendants, then this scenario for the nuisance action may make sense, ${ }^{96}$ but the source of the problem has now shifted, because collusion and extortion are different phenomena.

The plaintiff's attorney today faces the prospect of extended litigation in derivative actions. This pattern seems inconsistent with the "quiet extortion" scenario, and also implies that the payoff to the plaintiff's attorney may be reduced by an amount that offsets the litigation

96. In fact, nonpecuniary settlements under which most or all of the defendants' financial contribution goes to the plaintiff's attorneys have become common in Delaware. See infra note 129 and accompanying text. 
incentive created by a cost differential. In a 1984 case, a Delaware court observed that current defense tactics in derivative litigation, which involve appointing a special litigation committee of "disinterested" directors to study the charges made by the plaintiff and evaluate their impact on the corporation, prevent the plaintiff from reaching the merits of the case "for approximately two years at a minimum while the Committee goes through its functions." 97 If the plaintiff's attorney realizes at the outset that a two-year delay is likely before even discovery can be obtained, then the attorney should also recognize that this delay will at least partially offset any cost differential favoring plaintiffs. Moreover, if such a delay is indeed typical, then defendants would seem to be resisting the alleged extortionate advantage that the cost differential gives the plaintiff's attorney. Certainly, a two-year preliminary skirmish is inconsistent with the extortion scenario of quick, cheap settlements. Also, as the trial date nears, the cost differential advantage seems likely to fade in significance because the discovery stage is where the plaintiffs have their primary advantage. Thus, "late" settlements would seem more likely to be based on the litigation odds, with defendants disregarding prior expenditures as irrelevant sunk costs.

\section{B. A Portfolio Theory Perspective}

In those areas of litigation where client control over the plaintiff's attorney is weak, a disparity seems likely to exist between the adversaries' respective attitudes toward risk. As much as the asymmetric character of the stakes, this factor could explain the apparent "optimism" of the plaintiff's attorney in the face of a low rate of litigated victories. As a starting point, it seems reasonable to hypothesize that plaintiff's attorneys are typically repeat players who are accustomed to facing litigation risks. In contrast, the only study on the rate of litigation against corporate personnel suggests that, whether the action is a securities class action or a derivative suit, defendants (especially the individual defendants) are not accustomed to being sued.98 Thus, even if the stakes were equal, this differential in the parties' relative familiarity with litigation could explain why "one-shot" defendants would behave in a

97. Kaplan v. Wyatt, 484 A.2d 501, 511-12 (Del. Ch. 1984), aff'd, 499 A.2d 1184 (Del. 1985).

98. In his survey, Professor Jones found that a derivative or class action is brought against the typical publicly held corporation once every 6.7 years. Jones, An Empirical Examination of the Incidence of Shareholder Derivative and Class Action Lawsuits, 1971-1978, 60 B.U.L. Rev. 306, 312 (1980). More probatively, however, the study also revealed that a "disputed issue" (such as a self-dealing transaction) gives rise to litigation on the average of once every 17.5 years. Id. This difference is explained by the tendency of a single transaction to produce multiple actions in different courts or grounded on different theories. Of course, directors serving on more than one board could experience a higher rate of litigation. And a higher rate also applied to the very largest corporations in Jones' study. Id. at 316 (largest 80 firms sued every 3.6 years, and faced litigation from a "disputed issue" once every 11.4 years). 
more risk averse fashion than their more legally experienced adversaries. ${ }^{99}$ In addition, there is a distinct possibility that plaintiff's attorneys, being a self-selected population, may be disproportionately composed of risk preferrers who are willing to gamble on winning one large recovery.

More importantly, plaintiff's attorneys may possess a superior ability to spread their risks. As a professional litigator, and thus a repeat player, the typical plaintiff's attorney is likely to handle a number of cases simultaneously. The attorney thus has a portfolio of investments in litigation; in contrast, the typical defendant is a one-shot player. This contrast is similar to that between a fully diversified investor and an investor who holds only a single speculative asset. Accordingly, although both sides may agree on a suits litigation odds, one-shot defendants are well aware that the expected outcome is only a weighted average of the possible outcomes and that any outcome could in fact occur. Of course, deviations from the mean should even out over the long run, but only the plaintiff's attorney has a diversified portfolio and can afford to take the long-run view. Phrased more generally, portfolio diversification is a strategy that permits the plaintiff's attorney, much as any investor, to reduce the variance associated with an expected return. Hence, the "diversified" plaintiff's attorney should behave like a risk neutral investor, ${ }^{100}$ and thus be indifferent between pursuing a case having a ten percent chance of returning a $\$ 10,000,000$ recovery and one having a fifty percent probability of a $\$ 2,000,000$ recovery. This willingness on the part of the plaintiff's attorney to pursue high risk gambles, so long as they have the same expected value as other cases having a higher probability of success but a lower possible recovery, could also explain the phenomenon of "strike suits." What looks like extortion to defendants may in fact reflect only risk neutral behavior when viewed from a more objective perspective.

In reality, however, matters may not be as simple as the foregoing theoretical analysis suggests. First, the existence of director and officer insurance means that the real defendant may be the insurance carrier who, like the plaintiff's attorney, is also a repeat player and therefore

99. See Galanter, Why the "Haves" Come Out Ahead: Speculations on the Limits of Legal Change, 9 Law \& Soc'y Rev. 95, 99-100 (1974).

100. For an explanation of the standard theory of portfolio diversification, see $R$. Brealey \& S. Myers, Principles of Corporate Finance 119-26, 140-50 (2d ed. 1984). Plaintiff's attorneys, however, cannot diversify their portfolios in the same sense as investors. Under standard portfolio theory, the investor can purchase "co-variant" securities so that most exogenous changes causing loss to one stock will cause gain to another. Attorneys, however, are constrained by custom, social convention, and legal ethics from taking inconsistent positions simultaneously in different cases. Also, plaintiff's attorneys are usually unable to obtain institutional clients, in part because of the skepticism with which plaintiff's attorneys are viewed by the more established defense bar. The net result is that the inability to hold "co-variant" investments in litigation produces suboptimal portfolio diversification. 
less likely to be risk averse. ${ }^{101}$ Equally important is the characteristically small size of plaintiff's attorneys' firms. ${ }^{102}$ On such a scale, it is doubtful that plaintiff's attorneys can achieve full diversification.

What factors explain the small and seemingly suboptimal size of plaintiff's firms? In theory, plaintiff's attorneys would appear to have everything to gain and nothing to lose by collectively pooling their individual actions into a larger plaintiff's law firm, thereby attaining a more efficient level of portfolio diversification. Yet such firms have simply not materialized. Most explanations seem unsatisfactory. One possibility is that imperfections in the capital market inhibit the growth of firm size. Plaintiff's firms depend almost solely on bank financing, ${ }^{103}$ and banks probably lack the ability to appraise the future earnings prospects of attorneys operating on a contingent fee basis (as compared to law firms with institutional clients). ${ }^{104}$ Still, this explanation does not answer why plaintiff's attorneys do not merge their practices precisely

101. For a discussion of the availability of director and officer insurance, see infra note 124 and accompanying text. Although insurance carriers are not "one-shot" players, they usually permit the actual defendants to select their own counsel. These attorneys, of course, represent the interests of those who have selected them. Thus, "risk averse" defendants may still control the handling of the litigation. Why are carriers seemingly passive in this respect? One plausible reason is that they may prefer to have the actual parties settle the action and then commence their own negotiations with the defendants as to the percentage of the loss they will pick up. In effect, this tactic gives insurance companies a second opportunity to contest liability. Refusals to honor insurance policies appear to be a recent pattern. See Greenhouse, Continental Illinois Gets Accord Plan, N.Y. Times, Nov. 21, 1985, at D4, col. 5 (insurers may refuse to honor policy with Continental lllinois board).

102. Not one of the well-known plaintiff's law firms that handle class and derivative actions appears on the 1985 list of the largest 500 law firms in the United States. According to that annual survey compiled by Legal Times, the largest law firm had 750 attorneys and the 500th largest had 54 attorneys. See Legal Times, Sept. 16, 1985, at 15-50 (Special Supplement). The largest plaintiff's firm specializing in securities and class action litigation is by common consensus Milberg, Weiss, Bershad, Specthrie \& Learch, which had 37 lawyers at the end of 1984. See Lawsuit Fever, Fortune, Nov. 26, 1984, at 151-52.

103. Plaintiff's firms lack access to the equity markets because legal ethics preclude any division of fees with a nonlawyer or the formation of a partnership with a nonlawyer. See Model Code of Professional Responsibility DR 3-102, DR 3-103 (1979); Model Rules of Professional Conduct Rule 5.4 (1983). The only source of debt financing available to the plaintiff's attorney today is commercial banks. Even if other institutional lenders made loans to plaintiff's firms, such creditors would find it as difficult as banks to monitor plaintiff's law firms.

104. While a law firm with traditional clients can provide a bank with retainer agreements and other assurances, contingent fee attorneys have few clients who can provide similar evidence of continuing business. This problem would not be insurmountable if banks had a sufficient incentive to learn more about this line of business and distinguish good credit risks from weak ones. However, the lending volume among plaintiff's attorneys is probably too low to justify much inquiry by banks. As a result, only the long-established plaintiff's firms will be able to borrow based on future earnings, and newer firms will be limited to the debt level that the personal assets of their partners can collateralize. 
in order to give financial institutions a more secure debtor. A second possible explanation is that legal ethics constrain the growth of plaintiff's firms. Arguably, plaintiff's attorneys cannot associate with firms having large institutional clients because conflicts of interest might arise and bar the plaintiff's attorneys from bringing an attractive case. ${ }^{105}$ This explanation, however, does not answer why such attorneys do not affiliate with attorneys whose practices produce stable cash flows but lack the potential for conflicts of interest (for example, matrimonial or criminal defense attorneys).

The best, if tentative, answer that can be given to this puzzle begins with the fact that a law firm is not simply a portfolio of lawsuits. Rather, a successful firm presupposes an effective monitoring and governing mechanism. The growth of plaintiff's firms may have been impeded by the difficulties of creating such a monitoring structure on a large firm scale. Plaintiff's firms seem inherently less stable than the more institutional firms in which defendant's attorneys practice. ${ }^{106}$ This instability is largely attributable to the high lateral mobility that successful plaintiff's attorneys enjoy. Because the reputations of plaintiff's attorneys as trial lawyers are personal and portable, plaintiff's firms lack the "firm specific" capital that serves as the social cement in institutional firms. ${ }^{107}$

Additionally, plaintiff's firms face unique organizational problems that are occasioned by the prospect of "shirking" and "case stealing." In the typical institutional firm, attorney's fees are billed on a periodic basis (at least quarterly) as they are earned. By contrast, in the typical plaintiff's firm, the fee recovery is deferred until cases are settled or resolved by judgment. Often, this deferral extends over several years or more. The result is two-fold. First, a plaintiff's attorney handling a lengthy action may behave opportunistically by withdrawing from the firm, settling the action, and then pocketing the attorney's fee personally, even though the attorney's former partners subsidized him during the long pendency of the action. To be sure, the former partners may be able to sue him for an accounting, ${ }^{108}$ and contractual agreements

105. Legal ethics provide that the conflict of one partner is imputed to the firm as a whole. See Model Rules of Professional Conduct Rule 1.10 (1983).

106. Instances of instability are comparatively easy to identify since even wellknown and successful plaintiff's firms have undergone fission. See Lewin, Belli Says Law Firm Thrives Despite Fights, N.Y. Times, Mar. 19, 1984, at D1, col. 1 (noting dissension within, and departures from, Melvin Belli's firm). In order to pursue the Corrugated Container litigation, in which they ultimately received a record recovery, Stephen Susman and several of his partners were forced to separate from their former firm and form a new one that invested $75 \%$ to $80 \%$ of its time on that case. See Lempert, Antitrust Lawyer Hopes Fee Will Confirm Vision, Legal Times, May 17, 1982, at 1, col. 1, 11, col. 1. Such a firm represents an extreme example of underdiversification.

107. Cf. Gilson \& Mnookin, Sharing Among Human Capitalists: An Economic Inquiry into the Corporate Law Firm and How Partners Split Profits, 37 Stan. L. Rev. 313, 353-71 (1985) (discussing how "firm specific" capital limits lateral mobility).

108. Although such an action has rarely been litigated, a few examples exist. See 
may also reduce the magnitude of this problem. ${ }^{109}$ Nonetheless, there is a greater monitoring problem posed by plaintiff's firms than institutional firms. In an institutional firm, it is difficult for a single partner to withdraw and take away a large client because the client may have come to depend upon the services of the firm as a whole (for instance, tax, corporate, and litigation services). Put simply, it appears easier to "steal" actions than clients. In consequence, plaintiff's firms tend to dissolve regularly, thus impeding the achievement of optimal portfolio size.

Second, it is easier to detect if a partner is shirking in an institutional firm because legal fees are generated on a current basis. By contrast, in a plaintiff's firm, it is much more difficult to assess the value of an action that a partner has litigated for several years. Indeed, only an expert in such litigation can typically judge an action's prospects, and probably only after some extended inquiry. As a result, other practitioners with stable cash flows may have little interest in affiliating with a plaintiff's attorney because they cannot evaluate his practice and must subsidize him while he pursues a distant and speculative return. Put simply, a real estate, criminal law, or matrimonial specialist cannot affiliate with a plaintiff's attorney (at least where the latter's suits typically have an extended duration) unless they can monitor him, and typically they cannot.

The view that nonspecialist attorneys cannot easily monitor plaintiff's attorneys still does not explain why large firms composed solely of plaintiff's attorneys have not arisen. One possible answer is that the problems of "case stealing" and "shirking" make it more efficient for plaintiff's attorneys to organize on a "case specific" basis, rather than as a traditional firm. In recent large class actions, a unique institution, the "ad hoc" law firm, has appeared. "Ad hoc" firms, which are often composed of over one hundred attorneys under the direction of a steering committee, litigate the plaintiff's side of a case subject to court

Masters, Kreindler \& Kreindler Rupture: The Bad Blood Begins to Flow, Legal Times, Apr. 29, 1985, at 1, col. 2 (detailing suit for $\$ 700,000$ in litigation expenses between law firm and former partners with respect to cases pending at time of partners' departure).

109. The Kreindler \& Kreindler partnership agreement granted the firm's senior partner the right to split up compensation "for services rendered both before and after" the date on which partners withdrew from the firm. See id. at 6. This provision was intended to authorize the senior partner to allocate income received by a former partner on actions subsidized by the firm while the former partner was still a firm member. However, there are substantial questions about the enforceability of such an agreement, as it may amount to an impermissible fee sharing agreement. The partners who departed from Kreindler \& Kreindler raised this very claim. See id.; see also Model Rules of Professional Conduct Rule 1.5(e) (1983) (permitting reasonable and proportional division of fees among lawyers not of same firm only upon consent of client). State laws and legal ethics may also forbid any agreement that restricts the right of attorneys to practice law after their withdrawal from a partnership. See Gilson \& Mnookin, supra note 107, at 337 n.41 (citing California Rules of Professional Conduct 2-109 (1974)). 
oversight for a period that may last several years. ${ }^{110}$ Although there is considerable evidence of inefficiency and even chaos associated with the organization of such firms, ${ }^{11}$ there are reasons to believe that the development of this curious institution has inhibited the growth of more traditional plaintiff's firms. Initially, although any firm must incur monitoring costs, an "ad hoc" firm probably can better pass these costs on as allowable expenses in the fee petition. Because an "ad hoc" firm has a "case-specific" organizational structure, it need not concede that some reasonable expenditures should be allocated to a nonbillable overhead account. In contrast, the normal overhead costs in a traditional plaintiff's firm would properly be seen as nonspecific expenditures that could not be billed to any client.

Furthermore, the steering committee in such an "ad hoc" law firm may be better positioned to determine which attorneys are contributing to the team effort (and to give a greater and more highly compensated role to such attorneys) than the senior partner of a more hierarchically organized plaintiff's firm. Such a senior partner would have to monitor the efforts of some one hundred attorneys who were also involved in several dozen complex actions. In organizational terms, the senior partner's span of control is broader than the "ad hoc" steering committee's; hence, the monitoring may be less effective. The key point, however, is that given the necessity of a plaintiff's steering committee to administer a large class action, the use of a traditional firm's monitoring

110. For recent decisions that have described the nature of the "ad hoc" law firm, see In re "Agent Orange" Prod. Liab. Litig., 6I 1 F. Supp. 1296 (E.D.N.Y. 1985); In re Fine Paper Antitrust Litig., 98 F.R.D. 48 (E.D. Pa. I983), rev'd in part, 751 F.2d 562 (3d Cir. 1984). Fee petitions were submitted on behalf of over 100 attorneys in the Agent Orange litigation. For a description of these and other recent cases of similar size, see Coffee, Plaintiff as Monitor, supra note 5 , at 50 n.138.

111. Essentially, the "ad hoc" firm arises not by voluntary association, but from the direction of the Judicial Panel on Multi-District Litigation. This Panel consolidates the numerous class actions that are filed in a major antitrust, securities, or mass tort case before a single court. The Manual for Complex Litigation formerly advised the district court to let the attorneys select their own lead counsel. See supra note 42 . The result was often a hastily organized political convention at which log-rolling tactics and patronage agreements were used to secure the election of the lead counsel. See Coffee, Private Attorney General, supra note 5, at 249-6I. The elections were important because the lead counsel controls the "ad hoc" firm's work assignments (and thus fees). The 1985 revision of the Manual for Complex Litigation no longer counsels that attorneys select their own lead counsel. See supra note 42. Nonetheless, the Manual still gives attorneys substantial voice in determining the makeup of an "ad hoc" firm's leadership. Id. Further, attorney disputes over leadership and committee membership continue to disrnpt "ad hoc" firms. See Moore, Divisions over Stategy Erupt in Dalkon Shield Plaintiffs' Camp, Legal Times, Mar. I0, 1986, at 1, col. 4. On a few occasions, "ad hoc" firms have formed through a voluntary process rather than through Judicial Panel consolidation before one court. See In re "Agent Orange" Prod. Liab. Litig., 506 F. Supp. 762, 788 n.32 (E.D.N.Y. 1980) (describing formation of Yannacone and Associates), cert. denied sub nom. Diamond Shamrock Chem. Co. v. Ryan, 465 U.S. 1067 (I984). 
structure may involve a redundancy. If the plaintiff's attorneys in an action all belong to various large plaintiff's law firms, there would be duplication in overhead because each firm's monitoring structure would either conflict with, or be rendered superfluous by, the steering committee with respect to that action. This duplication in internal control procedures may partially explain why individual plaintiff's attorneys fear that a large firm structure would impose excessively "bureaucratic" constraints on their practices.

Finally, the need for a very detailed and potentially oppressive contract to prevent "case stealing" is largely eliminated when work is organized on a "case-specific" basis. The unique organizational structure of plaintiff's litigation, under which plaintiff's attorneys associate within both a small permanent firm and a large temporary "ad hoc" firm, can be viewed as a means of economizing on transaction costs. ${ }^{112}$ To be sure, these costs could be reduced still further, but the development of larger, permanent plaintiff's firms might simply add to the administrative overhead.

Besides the advent of "ad hoc" firms, other factors may inhibit the growth of large plaintiff's law firms. Such firms may not exist because their capacity to achieve diversification with respect to a portfolio of class actions may have less value than would be expected. Traditionally, plaintiff's attorneys in the personal injury field probably attained efficient diversifiction by handling a large inventory of cases that turned over quickly. In contrast, the procedural complexity and slow pace of the typical class action litigation leave only very large firms capable of diversifying their portfolios. Yet in some contexts, diversification may be less important than a tactic that increases the total damages likely to be awarded. For example, in the burgeoning products liability field, some plaintiff's attorneys argue that the class action device favors defendants, and that a better litigation strategy is to file numerous individual actions in state courts that cannot be consolidated in a single forum. ${ }^{113}$ To facilitate this strategy, these plaintiff's attorneys have developed elaborate litigation information networks through which scientific data, pleadings, and depositions can be shared. ${ }^{114}$ This system of

112. For a description of the transaction cost approach to understanding institutional structures, see Williamson, Transaction-Cost Economics: The Governance of Contractual Relations, 22 J.L. \& Econ. 233 (1979). Essentially, this approach seeks to understand why some transactions are organized within firms while others occur across markets. The article answers that firms are used in preference to the market when they can reduce the transaction cost of effecting a particular recurring transaction.

113. Plaintiff's attorneys believe that a single nationwide class action may favor the defendant by giving it a single forum within which to resolve the dispute and a judge who may limit the damages awarded for fear of rendering the defendant insolvent. See Wagner, supra note 1, at 46, 48 (quoting Michael Ciresi on plaintiff's strategy of using litigation networks in Dalkon Shield cases, and Thomas Henderson on why some plaintiff's attorneys believe class action format favors defendants).

114. For an overview of this development, see Galanter, Lawyers' Litigation Net- 
networking has developed to the greatest extent in the "mass tort" field, possibly because the incidence of recurring cases is too low and the nature of the factual research, which frequently involves highly technical medical or scientific issues, is too "case specific" for individual firms to invest in acquiring expertise in advance. Arguably, this dispersed institutional structure enables plaintiff's attorneys to conduct a more effective litigation campaigu against a single major defendant because the instigation of multiple lawsuits maximizes the plaintiff's cost differential. This effect would be lost if a larger plaintiff's firm sought to represent all the plaintiffs in a single action. Alternatively, this approach may allow plaintiff's attorneys to charge higher fees because the fee in an individual suit is the subject of bargaining between lawyer and client rather than the product of judicial decision. ${ }^{115}$ In either case, economic incentives suggest that the current structure of dispersed small plaintiff's firms will persist, in part because litigation costs can be shared through the network format.

In addition, the solo practitioner may be able to spread risks without affiliating with others through a "second best" technique that may help explain the phenomenon of nuisance suits. Although the individual attorney who handles securities or derivative actions cannot effectively litigate a sufficient number of actions to achieve efficient diversification, such an attorney can deliberately bring a large number of actions and devote relatively little time or energy to any single case. To be sure, this low intensity strategy means that each individual suit will have a lower expected value than it would have had if more time, effort, and money had been invested in its preparation. Yet this litigation strategy does permit risk spreading. In this light, the classic nuisance action-that is, a slapdash action that is inadequately researched and prepared and on which little attorney time is expended-may be less an extortionate attempt to exploit the cost differential that favors plaintiff's attorneys than a means of achieving the only form of risk

works (paper presented to the Conference on Frontiers of Research on Litigation, University of Wisconsin, Sept. 20, 1985) (on file at the offices of the Columbia Law Review).

115. In a series of recent class actions, a major division has erupted within the plaintiffs' camps between "traditional" plaintiff's attorneys, who favor individual trials, and class action attorneys, who favor a collective resolution of the mass injury and an equitable sharing of the recovery. See Lauter, Dalkon Shield Cases Thrown Into Disarray, Nat'l L.J., Mar. 17, 1986, at 1, col. 3, 10, col. 1 (noting disputes among plaintiff's attorneys in Dalkon Shield, Hyatt Regency, Agent Orange, Mansville, Bendectin, and Union Carbide class actions). Divergent economic incentives at least contribute to this dispute. The "traditional" plaintiff's attorney who pursues an individual trial may expect, say, a $\$ 1,000,000$ damage recovery, out of which he may receive $40 \%$ (or more) in fees pursuant to private agreement. In a class action, however, the plaintiffs may receive equal awards of, say, $\$ 50,000$, with smaller, judicially determined fee awards going to the attorneys. This tension obviously contributes to the instability and inefficiency of the "ad hoc" plaintiff's firm. As a result, the "traditional" plaintiff's attorney seeks to opt out of the class action in part to receive higher, privately negotiated fees, while the "new breed" of class action plaintiff's attorneys seek to negotiate a global settlement. 
spreading available to plaintiff's attorneys in small firms. In effect, such attorneys may restrict their investment of time and money in any individual case just as intelligent speculators may adopt self-imposed trading rules that limit their investment in any one stock.

This shotgun approach to ligitation may also permit plaintiff's attorneys to exploit the possibility that they will fortuitously uncover a "smoking gun" in the form of highly damaging evidence after incurring only minimal search costs. Bringing a large number of actions thus may be an efficient search strategy. If no such damaging evidence is uncovered after limited discovery, the plaintiff's attorney may cease to pursue the case in an intensive fashion and simply seek to exploit the cost differential as a basis for securing a modest settlement. Under this interpretation, nuisance actions can be viewed as the residue of cases in which a limited search has proven unfruitful.

A final aspect of the risk aversion differential between the parties involves the attitude of the defendant's counsel. Although more closely monitored and hence less able to behave opportunistically than plaintiff's attorneys, defendant's attorneys have a special reason to be risk averse: by losing an important case, defense attorneys can lose a client and thus incur a reduction in future business across a broad spectrum of transactions. ${ }^{116}$ For example, if the defendant is a law firm's major institutional client (such as a commercial bank or an investment banking house), an adverse verdict in an important case may be blamed on the law firm, thereby jeopardizing future business relations. Indeed, in the increasingly competitive marketplace for legal services, one may expect that other law firms will discretely suggest to the client that the case was mishandled or that it should have been settled and not tried. In short, at the attorney's level, the stakes are asymmetric in a different sense, because the defendant's attorney can lose a long-term client as a result of an adverse verdict, while the plaintiff's attorney has no real client to lose.

\section{Strategic Behavior}

If we recognize that plaintiff's attorneys are "repeat players" who may manage a portfolio of actions, and thus might rationally make litigation decisions based on their portfolio-wide impact, another explana-

116. This fear of losing a client may explain why large firms often retained an outside special trial counsel even though they had experienced litigators in their midsts. These special trial counsel (Lloyd Striker and Simon Rifkind were well-known examples) would be retained by the defendant's usual law firm for an important trial, even though this act implicitly conceded the law firm's lesser standing in the field of litigation. The advantage to the firm was that these "trial experts" served as buffers if a verdict went against their side. By avoiding blame for defeat in this manner, firms minimized the risk of losing an important client. More recently, as litigation has come to account for an increasing share of large firms' revenues, this strategy is no longer feasible. As a result, firms may be even more risk averse than before. 
tion comes into focus for the apparent excessive optimism of plaintiff's attorneys and their low rate of litigated victories: such an attorney may gain a long-term advantage by demonstrating a willingness to go to trial. Although a refusal to accept a reasonable settlement offer may be illogical in terms of an individual case, such a refusal may signal a plaintiff's attorney's toughness at bargaining, which could enhance his position in future settlement negotiations. Willingness to go to trial distinguishes this attorney from others who seldom try their cases. Even more importantly, a litigated victory may significantly enhance a lawyer's reputation; thereafter, the attorney becomes known within the profession as "the guy who won the Amalgamated Widget case."

For plaintiff's attorneys, reputation has special importance because they are not associated with an institutional firm that possesses its own prestige. Also, because the "ad hoc" plaintiff's firm that assembles to litigate a major class action is only loosely organized, the reputations of the plaintiff's attorneys will affect their rank and seniority in the firm. Predictably, an attorney who is granted membership on the steering committee that runs the plaintiffs' side of the action will be more highly compensated than an attorney who simply conducts discovery for the plaintiffs' team-even in the unlikely event that both work an equivalent number of billable hours. ${ }^{117}$ In effect, plaintiff's attorneys engage in a two-front career battle: they wish both to be recognized and respected by their adversaries (because this affects settlement negotiations) and to achieve status within the fluid world of the plaintiff's bar (because this predictably entitles them to a more senior position on the plaintiff's team). Winning a publicized victory can be the best route to both ends.

Defendants, too, may rationally engage in strategic behavior if they are repeat players. Thus, insurance companies or accounting firms that expect to be sued recurrently may strive to establish reputations as tough negotiators who will not settle easily, even if this posture costs them an occasional litigated defeat. Still, most defendants in the fields of antitrust, securities, and derivative actions are not repeat players. One survey indicates that the typical large American corporation should expect that its conduct will lead to derivative or securities class litigation at the rate of less than once a decade. ${ }^{118}$ Because defendants both have greater control over their attorneys and are not "repeat players," a higher rate of strategic behavior should be anticipated from

117. In part, this incentive for plaintiff's attorneys to hold a senior position in an "ad hoc" firm arises because they are more likely to obtain fee petition approval if they are visible to the court and to receive a contingency bonus under the lodestar formula. As The American Lawyer succinctly stated in describing the Fine Paper case: "Titles were a valued commodity, since lawyers in 'leadership' roles can more easily petition the court for fee 'multipliers,' allowing them to double or triple their normal hourly billings." Reading Moody's at $\$ 682$ an Hour, Am. Law., Jan. 1982, at 31, col. 2.

118. See Jones, supra note 98 , at 316 (largest 80 firms in survey litigated a "disputed issue" once every 11.4 years). 
plaintiff's attorneys than from defense attorneys. This, in turn, should be reflected in a lower rate of litigated victories for plaintiffs. This prediction, as noted earlier, ${ }^{119}$ appears consistent with the available data.

\section{The Problem of Collusion: Litigation As a Non-Zero Sum Game}

The principal-agent problem that is endemic to class and derivative actions implies that there are three sets of interests involved in these actions: those of the defendants, the plaintiffs, and the plaintiff's attorneys. Often, the plaintiff's attorneys and the defendants can settle on a basis that is adverse to the interests of the plaintiffs. ${ }^{120}$ At its worst, the settlement process may amount to a covert exchange of a cheap settlement for a high award of attorney's fees. Although courts have long recognized this danger and have developed some procedural safeguards intended to prevent collusive settlements, these reforms are far from adequate to the task. ${ }^{121}$

Indeed, in some areas, the law seems almost to have institutionalized a process which ensures that a case will be settled on a basis that need not closely reflect the litigation odds. The derivative action supplies the best example. Under well-established rules, the corporation pays the plaintiff's attorney's fees when the action produces a substan-

119. See supra notes $81-86$ and accompanying text.

120. See infra note 129 and accompanying text.

121. Judge Henry Friendly observed that "[a]ll the dynamics conduce to judicial approval of [the] settlement[]" once the adversaries have agreed. See Alleghany Corp. v. Kirby, 333 F.2d 327, 347 (2d Cir. 1964) (Friendly, J., dissenting), aff'd en banc by equally divided court, 340 F.2d 311 (2d Cir. 1965), cert. dismissed, 384 U.S. 28 (1966). Although the case law may require full and elaborate judicial review before a settlement is approved, it is doubtful that courts have much incentive to be very demanding. Their deferential attitude is probably best expressed by one recent decision which acknowledged that: "In deciding whether to approve this settlement proposal, the court starts from the familiar axiom that a bad settlement is almost always better than a good trial." In re Warner Communications Sec. Litig., 618 F. Supp. 735, 740 (S.D.N.Y. 1985). Empirical evidence also suggests that judicial monitoring of class action settlements is relatively slack. See Rosenfield, An Empirical Test of Class-Action Settlement, $5 \mathrm{~J}$. Legal Stud. 113, 119 (1976) (settlements of class action suits tend to result in monetary bonuses to attorneys at the expense of class' interests). Indeed, not only do courts lack any incentive to oppose proposed settlements, but unless an objector appears on the scene, they have little independent access to information about the merits of the settlement. For a recent critical review of the adequacy of existing procedures, see Note, Derivative Suit Settlements: In Search of a New Lodestar, Law \& Contemp. Probs., Summer 1985, at 229. Even when a settlement is rejected, the result may only be to continue a seemingly interminable action. In this regard, Piambino v. Bailey, 757 F.2d 1112 (11th Cir. 1985), is depressingly instructive. In Piambino, the circuit court in 1985 justifiably overturned an obviously improper settlement that was reached in 1977 of an action commenced in 1973. Thus, a dozen years after the action's commencement, the matter is still pending and the ultimate outcome is not yet in sight. The fact that the decision appears to have been justified hardly proves that a judicial approval requirement is sufficient to deal with the problem of cheap settlements. 
tial benefit to the corporation. ${ }^{122}$ Correspondingly, the corporation is permitted to indemnify defendant corporate officials for their legal expenses incurred in connection with a derivative action. ${ }^{123}$ Many large corporations have adopted by-laws authorizing such indemnification to the full extent permitted by law, and virtually every corporation listed on a national securities exchange purchases liability insurance for its corporate officials covering such legal expenses. ${ }^{124}$ Restrictions exist, however, on the availability of both insurance and indemnification: typically, the corporation may not indemnify a defendant's litigation expenses when he has been "adjudicated" to have breached a duty to the corporation. ${ }^{125}$ Also, as a matter of both law and insurance contract provisions, insurance does not cover liability for fraud or unfair selfdealing. ${ }^{126}$ Hence, powerful pressures to settle exist because each side can assure itself that its legal fees will be reimbursed in the wake of a settlement. ${ }^{127}$ The defendants will avoid being "adjudicated" to have breached a duty and can characterize the nature of the liabilities so as to

122. See Shlensky v. Dorsey, 574 F.2d 131, 149 (3d Cir. 1978); H. Henn \& J. Alexander, Laws of Corporations 1108-10 (3d ed. 1983).

123. See, e.g., Cal. Corp. Code $\S 317(c)(1)$ (West Supp. 1986); N.Y. Bus. Corp. Law $\S 722$ (a) (McKinney Supp. 1986); J. Bishop, The Law of Corporate Officers and Directors: Indemnification and Insurance ch. 6 (1981).

124. See The Wyatt Co., 1984 Wyatt Directors and Officers Fiduciary Liability Survey 70-71 (1984). This survey by a leading insurance consulting firm shows that during $1984,98.1 \%$ of all New York Stock Exchange listed firms and 98.4\% of all American Stock Exchange listed firms carried director and officer liability insurance. However, a number of companies have begun to experience difficulty in finding and affording such insurance. See Lewin, Director Insurance Drying Up, N.Y. Times, Mar. 7, 1986, at D1, col. 3.

125. See, e.g., N.Y. Bus. Corp. Law $\S 722$ (a) (McKinney Supp. 1986) (corporation may not indemnify any defendant in a derivative action "in relation to matters as to which such director or officer is adjudged to have breached his duty to the corporation"). Because settlements do not "adjudge the defendant to have breached his duty to the corporation" (in the language of the typical statute), they pose no barrier to indemnification of litigation expenses.

126. See N.Y. Bus. Corp. Law $\S 727$ (b)(1) (McKinney Supp. 1986) (providing that insurance may not cover payments if judgment establishes that insured "personally gained in fact a financial profit or other advantage to which he was not legally entitled"). There are also common law limits on the enforceability of insurance for intentional misconduct. See, e.g., Portaro v. American Guar. \& Liab. Ins. Co., 2 I0 F. Supp. 411, 416 (N.D. Ohio) (insurer not liable for damages caused by officer of insured for assault and battery), aff'd, 310 F.2d 897 (6th Cir. 1962). Most standard policies also contain a contractual exclusion for "personal benefit" and "dishonesty." See Hinsey, The New Lloyd's Policy Form for Directors and Officers Liability Insurance-An Analysis, 33 Bus. Law. 196I, 1969-71 (1978).

127. This incentive to settle in order to obtain legal expense reimbursement is particularly strong in the context of claims against directors and officers. The 1984 Wyatt Survey shows that the average cost of defending a claim brought against a corporate officer or director has risen to $\$ 461,000$, and the average settlement increased to $\$ 583,000$. See Schatz, supra note 94 , at F13, col. 2 . Together, these figures imply that litigation expenses amount to roughly $45 \%$ of the total claims made to insurers under director and officer policies. 
permit insurance to cover these payments. ${ }^{128}$

Of course, the defendants' settlement calculus must also include any payments they must make to the corporation. However, this payment may be trivialized or rendered nonexistent if certain forms of settlement, which are attractive to both sides, can be arranged. Recent precedents have approved wholly nonpecuniary settlements in which the defendants did not contribute any cash or property to the settlement fund. ${ }^{129}$ Instead, the only relief received by the corporation was therapeutic: disclosures were made, by-laws were revised, and new board procedures were adopted. The availability of these bloodless settlements gives rise to a set of circumstances in which it can appear economically irrational not to settle. By settling, neither side loses anything, and both recoup their legal expenses from the corporation (and thus indirectly from the shareholders).

Notwithstanding this logical description of how the principal adversaries can settle collusively at the expense of the shareholders, experienced litigators will dispute the accuracy of this account. They will respond that in their entire experience they have never seen anyone offer or agree to swap a high fee award for a low recovery. Indeed, this response is probably accurate, because there is one further nuance that must be understood in order to comprehend settlement dynamics.

128. Insurance may cover "due care" liabilities, but not most duty of loyalty liabilities. See supra note 126 . Thus, it is in the interests of the parties to characterize the settlement of a "duty of loyalty" case as a "duty of care" settlement. In practice, claims alleging director negligence have little intrinsic settlement value because of the protection given corporate officials by the business judgment rule. Yet both sides can happily settle on the basis of the duty of loyalty claim (where the business judgment rule is inapplicable) and describe it to the world as a due care settlement. Of course, insurers are adverse parties to such settlements, but they may prefer to negotiate with the defendants and reach a private settlement, rather than appear to "welch" on their policies.

129. Several of these settlements have been reviewed and criticized by the author elsewhere. See Coffee, Plaintiff as Monitor, supra note 5, at 26-33. More recently, the Delaware Supreme Court has held in connection with a case approving a settlement where no pecuniary relief was secured to the plaintiff shareholders, that it would reverse a lower court's approval of a derivative suit settlement only if it finds "the cvidence is so strongly to the contrary as to amount to an abuse of discretion." Polk v. Good, 1986 Fed. Sec. L. Rep. (CCH) \ 92,530 at 93,177 (Del. Mar. 10, 1986). For an analysis of the rule that permits corporations to pay a fee to the plaintiff's attorncys even though no tangible recovery is obtained, see Note, Attorneys' Fees in Shareholder Derivative Suits: The Substantial Benefit Rule Reexamined, 60 Calif. L. Rev. 164 (1972). Some courts have even rationalized that a substantial benefit sufficient to justify a fee award was conferred when the action was dismissed, on the theory that the corporation was thereby "spared" greater expense. See, e.g., Weisberg v. Coastal States Gas Corp., [1982 Transfer Binder] Fed. Sec. L. Rep. (CCH) ๆ 98,716, at 93,589 (S.D.N.Y. June, 16, 1982); Lewis v. Anderson, 81 F.R.D. 436, 439 (S.D.N.Y. 1978). Once the "benefit" consists of not causing the corporation further expense, it becomes difficult to distinguish this benefit from extortion. To restrict settlements of this variety, the author in his role as Reporter to the American Law Institute has proposed that the fee awarded by courts not exceed a "reasonable percentage of the total recovery." See American Law Institute, supra note $1, \S 7.17 \&$ comment a. 
This factor involves the impact of the now prevailing method of awarding attorney's fees. The lodestar formula ${ }^{130}$ compensates the attorney based essentially on the time the attorney expends on the action, rather than simply awarding the attcrney a percentage of the recovery. While some have criticized the lodestar formula on the ground that it encourages an attorney to expend excessive time on an action (because it equates time with money), ${ }^{131}$ this analysis misses the formula's real impact. Essentially, the lodestar formula enables collusion to occur on an implicit, rather than explicit, basis. Collusion becomes structural, not actual, because the fee award is no longer a simple function of the recovery.

To see this, consider the position of a plaintiff's attorney who invests a year's effort in preparing a case for trial. Assume the case has an expected value to the class of $\$ 4,000,000$ (meaning that the plaintiffs would reject any lesser settlement and take their chances at trial). Assume further that the attorney historically would have received a fee award of $\$ 1,000,000$ based on a percentage of the recovery benchmark of twenty-five percent, but that today the attorney is instead compensated based on the time reasonably expended on the action. Assume finally that on the eve of trial, the attorney has already expended sufficient time to justify a $\$ 1,000,000$ fee award on an hourly basis, and that there is also a substantial litigation risk that the judgment (if the attorney goes to trial) will be adverse to his side (in which case the attorney will receive nothing). If defendants now offer a settlement of only $\$ 2,000,000$, there is little reason for the attorney to decline this settlement, even though the plaintiffs would prefer to hold out for $\$ 4,000,000$. That is, when fees are based on the lodestar formula, the plaintiff's attorney receives the same fee award under the proposed settlement as if the plaintiffs had won a much larger victory at trial. In addition, the attorney avoids the substantial risk of an adverse decision. Indeed, if the attorney won a $\$ 10,000,000$ verdict at trial, he would gain little incremental benefit because the time expended in trying the case probably would not materially enhance the fee award, but the attorney would have had to accept a significant risk that his substantial investment of time would go uncompensated. ${ }^{132}$ In effect, under the lodestar

130. See supra notes $16-17,26,59$ and accompanying text.

131. See In re Fine Paper Antitrust Litig., 98 F.R.D. 48, 68, 85 (E.D. Pa. 1983), rev'd in part, 751 F.2d 562 (3d Cir. 1984); A. Miller, Attorneys' Fees in Class Actions 270-71 (1980); Solovy \& Mendillo, Calculating Class Action Awards: Is It Time to Unload the Lodestar?, Nat'l L.J., May 2, 1983, at 20, col. 3; Wolfram, The Second Set of Players: Lawyers, Fee Shifting, and the Limits of Professional Discipline, Law \& Contemp. Probs., Winter 1984, at 293, 302. For the recent criticism of the lodestar formula by a Third Circuit task force, see Task Force, supra note 17, at 15-19.

132. To be sure, trial involves some additional hours and thus will increase the lodestar fee award. Nonetheless, this does not alter the foregoing analysis because a settlement offer could be made and accepted at the conclusion of the trial before the judge or jury reaches a verdict. Such a delayed offer would permit the plaintiff's attor- 
formula, a plaintiff's attorney shares his clients' downside risk, but not their upside gain, by rejecting a settlement and proceeding to trial.

Of course, the plaintiff's attorney may procrastinate and seek to build up the expected fee award from $\$ 1,000,000$ to, say, $\$ 1,250,000$. This obvious incentive for delay under the lodestar formula, which would not arise under a percentage of the recovery formula, helps explain the popular impression that it produces makework and padded bills. Nonetheless, the critical point is that the formula produces de facto collusion that each side can rationalize. The defendant's counsel has every reason to make a low settlement offer. Similarly, defense counsel can happily oblige the plaintiff's attorney's procrastination while the latter builds up the fee to the maximum level that the court will allow. The plaintiff's attorney can rationalize a low settlement on any of a variety of grounds: the risk of an adverse verdict, the suspected hostility of the court, the impact of delay on the class, or the increased expenses for the class if the action continues. At no point must either side actually link the fee award and the settlement size in their negotiations-the law does this for them by tying fee awards to hours billed rather than settlement size. Once the plaintiff's attorney is able to estimate the fee award simply by computing the hours expended, he does not need a collusive offer from the defendants, but merely their acquiescence in a strategy that maximizes the interests of both sides. In short, under the lodestar formula, actual collusion is replaced by structural collusion.

Once polite collusion becomes possible in this manner, it affects the quality of the cases that plaintiff's attorneys will bring in the long run. Plaintiff's attorneys have less reason to screen their cases and may bring weak cases whose settlement value, when based simply on the litigation odds, would not normally cover the attorneys' opportunity costs. Defendants will sometimes resist settlement in these cases; for example, they may see a reputational injury or view themselves as repeat players. As a result, the cases that go to trial will be disproportionately weak ones for plaintiffs, given defendants' strong motivation to settle any case other than a frivolous one. Once again, litigated cases will constitute a very biased sample of all cases that are filed, and so will tell us little about the meritoriousness of the average case.

Collusion can also occur in ways that depend more on the defendants' behavior than on that of the plaintiff's attorneys. By several techniques, individual defendants can seek to transmute their personal liability into corporate liability. Derivative actions against corporate officials are frequently brought in tandem with class actions against the

ney to bill for the additional hours at trial. Hence, there is always a point where accepting the risk of an adverse decision does not carry even the slightest prospect of an increased fee award under the lodestar formula. Nor is the litigation risk a small one for the plaintiff's attorneys in this field. See supra notes 81-84 and accompanying text. 
corporation that allege violations of the federal securities laws. ${ }^{133}$ In such instances, the individual defendants may find it in their interest to offer a generous settlement on the claims brought against the corporation in return for a cheap settlement of the derivative action against themselves. Plaintiff's attorneys may see little reason to resist this offer because their duty (as they perceive it) is to maximize the plaintiff class' recovery, not to administer punishment. Thus, plaintiff's attorneys can be relatively indifferent to the issue critical to the defendants: namely, who pays. This pattern of transmuting individual liability into corporate liability can even arise in class actions that essentially allege insider trading by corporate executives. Notwithstanding the clear liability of the individual defendants, the great bulk of the settlement fund can come from their corporate employer, which may not have traded but which will also be sued under Rule $10 \mathrm{~b}-5$ for making misleading public disclosures. ${ }^{134}$ The net result is that settlements can be reached that

133. The filing of tandem actions both enables plaintiffs to maintain the action in one capacity if they are found to lack standing in the other capacity and makes possible a global settlement in one courtroom. Absent this practice, upon settling a direct action, defendants would fear that the same allegations might be pleaded again as a derivative action by other plaintiffs. Thus, the settlement of direct claims would not collaterally estop the derivative claims, because different plaintiffs would be asserting claims involving distinct injuries. Knowledge of this possibility should reduce the defendants' maximum settlement offer. As a result, both sides recognize the need to reach a contemporaneous settlement of all possible claims, both direct and derivative. For an example of such a tandem action, see In re Transocean Tender Offer Sec. Litig., $455 \mathrm{~F}$. Supp. 999 (N.D. Ill. 1978).

134. A good example is provided by In re Warner Communications Sec. Litig., 618 F. Supp. 735 (S.D.N.Y. 1985). Warner Communications began to experience a serious decline in the market acceptance of its Atari product line. Warner's executives realized that this decline would seriously erode the corporation's projected earnings. During a critical period just prior to the delayed announcement of its third quarter earnings, 13 Warner executives sold significant portions of their personal holdings in the company. Id. at 741. This pattern obviously suggested insider trading. Class and derivative actions were eventually brought in Delaware and the Southern District of New York against Warner for "fraud on the market," and against the individual defendants for insider trading. A fund of $\$ 17,500,000$ was eventually negotiated to settle both the state and federal claims. Id. at 753. The individual defendants contributed $\$ 2,000,000$ in the state proceeding, while the insurance carrier on the policy covering both the defendants and Warner paid $\$ 6,000,000$; the balance of roughly $\$ 9,500,000$ was paid by Warner. Because the premiums on director and officer insurance are invariably paid by the corporation (and increase after such a settlement), one can view this settlement as one in which the individual defendants contributed less than $12 \%$ of the total fund and did not disgorge their full insider trading gains. No suggestion is here intended that any impropriety attended the actual negotiation of this settlement; indeed, the total fee award to the plaintiff's attorney was slightly less than $25 \%$ of the settlement fund, which is fully in line with standard practice. Nonetheless, the parties most responsible for the violation of Rule 10b-5 (and the only parties able to profit from the entire set of events) still profited and escaped the bulk of the financial sanction. The lesson of Warner Communications may be that insider trading remains profitable so long as the insiders can transfer their liability to the corporation on the theory that the corporation misinformed the market. 
bear no relation to the litigation odds against the defendant who bears their cost. Eventually, settlements that shift these costs from officers to their corporations both rob the law of its deterrent impact and, paradoxically, force shareholders, who are the intended beneficiaries of the substantive legal standard, to bear the costs of the actions. ${ }^{135}$

\section{E. Perverse Reforms: The Curious Impact of Proposals to Curb "Frivolous" Litigation}

Although the preceding analysis does not refute the possibility of extortionate litigation, it does suggest that the collusion hypothesis has greater explanatory power. Against this backdrop, the impact of various proposals to control frivolous actions can be better understood. Historically, corporate law has relied on two principal methods of chilling nuisance actions: (1) the legislative attempt, which arose in the 1940 s, to curtail derivative actions by requiring that plaintiffs post a security for expenses bond as a precondition to maintaining a derivative action, ${ }^{136}$ and (2) the more recent judicial acceptance, largely dating from the $1970 \mathrm{~s}$, of the special litigation committee as a means by which a corporation's board of directors can effect the dismissal of a derivative action without substantive judicial review. ${ }^{137}$

What is the impact of each of these legal rules on the plaintiff's attorney? Essentially, a security for expenses bond represents a form of partial fee shifting. Hence, it should tend to discourage actions having a low probability of success at trial. ${ }^{138}$ Although the bond requirement

135. This tendency for the settlement cost in such litigation to be borne by the intended beneficiaries may partly explain the tendency for the market's reaction to the filing of a derivative suit to be statistically insignificant. See Fischel \& Bradley, supra note 9 , at $277-83$.

136. These statutes were largely passed in the wake of the Wood Report, which concluded that derivative actions were disproportionately nuisance suits because of their low rate of plaintiff victories. See supra note 10. The legal scholars of that era saw these statutes as overbroad and discriminatory. See Hornstein, supra note 82, at 128-29, 143. For more current assessments of their impact, which has clearly been more limited than anticipated, see Dykstra, The Revival of the Derivative Suit, 116 U. Pa. L. Rev, 74 (1967); Note, Security for Expenses in Shareholders' Derivative Suits: 23 Years' Experience, 4 Colum. J.L. \& Soc. Probs. 50 (1968).

137. The case law and secondary literature on this topic has become voluminous. For leading cases, see Zapata Corp. v. Maldonado, 430 A.2d 779 (Del. 1981); Auerbach v. Bennett, 47 N.Y.2d 619, 393 N.E.2d 994, 419 N.Y.S.2d 920 (1979). For an overview, see American Law lnstitute, supra note 1, § 7.08. More recently, in Aronson v. Lewis, 473 A.2d 805, 814 (Del. 1984), the Delaware Supreme Court held that demand on a board is not excused merely because the board approved the transaction challenged in the derivative suit. Where demand is not excused, the board can dismiss a derivative suit subject only to review under the business judgment rnle, thus avoiding the need to appoint a special litigation committee. Id. at 813 .

138. Two-way fee shifting increases the risk that a plaintiff who commences a nonmeritorious action will bear the defendant's legal expenses. For a formal statement of the proposition that fee shifting discourages suits with low probabilities of success, but encourages the filing of suits with high prospects of success, see Shavell, supra note 2, at 
will clearly discourage underfinanced plaintiff's attorneys, it may have less impact on better financed attorneys if they anticipate that collusive settlements are possible. So long as the adversaries find it in their interest to settle rather than fight, and settle on a basis not necessarily closely related to the litigation odds, then any proposal that relies at bottom on partial fee shifting can be expected to have only a limited impact on the incidence of derivative actions.

In contrast, the judicial acceptance of the special litigation committee significantly tilts the litigation odds against plaintiffs. Recent cases have permitted a board of directors, even if all of its members are legitimate defendants in a nonfrivolous case, to appoint two or three new directors to the board and constitute them as the special committee to review the action. ${ }^{139}$ On the evidence to date, it appears that these committees almost invariably recommend to dismiss derivative suits. ${ }^{140}$ Under the law of New York and Delaware, for example, substantive judicial review of such a committee's decision is generally unavailable. ${ }^{141}$ In principle, this development would seem to signal the death of the derivative suit. Yet the frequency of derivative actions has increased. ${ }^{142}$

74-75. Fee shifting, however, reverses any cost differential that may favor plaintiffs. Thus, fee shifting may have a greater impact on plaintiffs than defendants and could thereby discourage even meritorious suits.

139. See Zapata Corp. v. Maldonado, 430 A.2d 779 (Del. 1981); Auerbach v. Bennett, 47 N.Y.2d 619, 393 N.E.2d 994, 419 N.Y.S.2d 920 (1979). For a review of cases decided as of May 1981, see Coffee \& Schwartz, The Survival of the Derivative Suit: An Evaluation and a Proposal for Legislative Reform, 81 Colum. L. Rev. 261 (1981). In a few cases, however, courts have refused to accept such a delegation of authority to a litigation committee when the board was controlled by the defendants in the action. See Miller v. Register \& Tribune Syndicate, 336 N.W.2d 709 (Iowa 1983); Alford v. Shaw, 72 N.C. App. 537, 324 S.E.2d 878, petition for review granted, 314 N.C. 114, 332 S.E.2d 478 (1985).

140. See Cox, Searching for the Corporation's Voice in Derivative Suit Litigation: A Critique of Zapata and the ALI Project, 1982 Duke L.J. 959, 963 \& nn.13-14 (citing reported cases as of 1982).

141. Under the law of Delaware, substantive judicial review of the litigation committee's decision to reject a derivative action will not be undertaken unless demand on the board would have been excused. This demand required-demand excused distinction is a highly formalistic one, and demand has not been excused in Delaware, even in an action against a controlling shareholder who founded the corporation and selected the other directors. See Aronson v. Lewis, 473 A.2d 805, 815-17 (Del. 1984). Essentially, New York courts may not review the substantive decision of the board or committee, although they must consider the procedures followed by the committee and any evidence bearing on the good faith of the committee, absent proof of actual bias. See Auerbach v. Bennett, 47 N.Y.2d 619, 631, 634, 393 N.E.2d 994, 1001, 1002, 419 N.Y.S.2d 920, 927, 929 (1979).

142. According to insurance industry data, liability claims under director and officer insurance policies have risen dramatically. The Wyatt Company reports that in $1984,18.5 \%$ of the companies they surveyed experienced such a claim against their directors, up from $7.1 \%$ in 1974 . See Schatz, supra note 94 , at F13, col. 2; see also Myrick \& Ochipinti, Corporate Officers, Directors Face Rise in Suits, Legal Fees, Legal Times, Feb. 4, 1985, at 3, col. 1 (noting 10\% increase in derivative litigation between 1982 and 1984). Multiple factors can explain this rise: the increased frequency of highly 


\section{What explains this?}

From this Article's perspective, the economic impact of the special litigation committee on "entrepreneurial" plaintiff's attorneys may be chiefly to change their tactics by reducing the investment that they will make in any action. The special litigation committee device is notoriously expensive and time-consuming: it may well cost over $\$ 1,000,000$ for special counsel and other out-of-pocket expenses, and take an average of two years to terminate an action. ${ }^{143}$ The very pendency of an action may also have various negative consequences for the corporation or the defendants. As a result, a plaintiff's attorney may be able to underbid the cost of the committee procedure. For example, suppose a derivative action contesting a self-dealing transaction is brought to recover an alleged corporate loss of $\$ 10,000,000$. In response, the board can appoint a special committee to study the action, and it can predict (with near certainty given the results to date) that, under Delaware or New York law, the study will result in the dismissal of the action within two years. Yet this process is expensive, and the inevitable delay may entail further costs. An alternative open to the corporation is to bribe the plaintiff's attorney to settle the action-for example, by offering $\$ 250,000$ in legal fees and a nonpecuniary cosmetic settlement. This latter course is cheaper and faster for the defendants than the special litigation committee technique, but it creates an incentive for further extortionate actions to be brought. To the extent that the defendants are repeat players or see reputational injury in settling, they may resist. Yet indirect evidence suggests that both strategies are frequently employed today, with cheap settlements being as popular as the technique of special litigation committee review and dismissal. ${ }^{144}$

visible transactions, such as golden parachutes and takeover defenses, the increased number of attorneys, and the increased detectability of insider trading violations because of new techniques and technologies available to the SEC.

143. For example, in Kaplan v. Wyatt, 484 A.2d 501 (Del. Ch. 1984), aff'd, 499 A.2d 1184 (Del. 1985), the court found that the special litigation committee's attorney's fees alone amounted to $\$ 500,000$, and that the two directors on the committee billed $\$ 17,500$ worth of time on the matter. Id. at 515 . Of course, these figures do not include the opportunity and out-of-pocket expenses of the corporation's officials, nor the indemnity that the corporation must pay the defendant directors if the action is dismissed. In addition, the court noted that litigation committees will generally delay an action for a minimum of two years. Id. at 511-12.

144. As earlier noted, survey data shows that in 1984 the average cost of defending a claim made against corporate directors was $\$ 461,000$, while the average settlement was $\$ 583,000$. See supra note 127. Chancellor Brown of Delaware found in Kaplan v. Wyatt that the cost of counsel to the special litigation committee alone was $\$ 500,000$. 484 A.2d 501, 511 (Del. Ch. 1984). This level of expenses could easily justify an early settlement of $\$ 500,000$ so that the corporation can avoid incurring $\$ 1,000,000$ in expenses and losing the time of its directors. In fact, however, carly settlements do not appear to be the norm. Possibly, this is because Delaware courts blend the lodestar and percentage of the recovery fee formulas, see Sugarland Indus. v. Thomas, 420 A.2d 142 , 150 (Del. 1980), thereby creating at least some incentive for delay. In addition, the initial reaction of directors, who are not used to being sued, appears to be to fight; 
Ex ante, the lesson that the profit-maximizing plaintiff's attorney should learn from this set of incentives is not to invest heavily in a single case. Because the litigation odds are stacked against them, plaintiff's attorneys may find that they can stay in business only by underbidding the cost of the special litigation committee. To do this and still earn an acceptable profit, they must radically reduce their costs and attempt to exploit the differential between their litigation costs and those of the defendants. The irony, then, is that although the special litigation committee device is intended to discourage nuisance actions, it may have the perverse effect of making the nuisance action the most rational strategy for plaintiff's attorneys to pursue. Indeed, as the plaintiff's attorneys' profit margin is eroded, a Gresham's law effect may take hold as "bad" plaintiff's attorneys begin to drive out the "good." Plaintiff's attorneys who are unwilling to engage in collusive settlements, or who have high opportunity costs, may simply leave the field, abandoning it either to those with lower opportunity costs or those less able to redeploy their invested human capital to some related field of litigation.

These observations about the special litigation committee inevitably lead us back to points earlier made in this Article. First, the disincentive that the special litigation committee creates for investment in an action exacerbates the basic tendency for plaintiff's litigation to be underfunded, which results from the fact that the litigation stakes are inherently asymmetric. Second, in terms of the potential disparity between the private and social costs and benefits of litigation, the continued availability of collusive settlements makes it possible that the private incentive to sue may well exceed the optimal social level. Conversely, to the extent that the high probability of dismissal regardless of an action's substantive legal merit deters plaintiff's attorneys from incurring search costs to discover meritorious legal actions, the incentive to litigate may be inadequate from a social perspective. Third, the cost differential that Professors Rosenberg and Shavell identified as the source of the plaintiff's extortionate power increases in the era of the special litigation committee. ${ }^{145}$ Thus, ironically, the true nuisance action may survive largely because of a remedy designed to extingnish it. When one takes account of the social costs associated with judicial monitoring of such litigation, the current state of the law may seem to resemble the worst of both worlds, since meritorious actions are chilled

settlement negotiations begin only after the depositions have made the defendants less eager for battle. The basic point here, however, is that the advent of the special litigation committee has raised the corporation's cost of defending derivative actions even as it has changed the litigation odds in favor of defendants. Thus, this procedure may have left a niche within which at least some plaintiff's attorneys can still do business.

145. See Rosenberg \& Shavell, supra note 8, at 9-10; see also Kaplan v. Wyatt, 484 A.2d 501, 511 (Del. Ch. 1984) (attorney's fees for special litigation committee totaled approximately $\$ 500,000$ ), aff'd, 499 A.2d 1184 (Del. 1985). 
and even frivolous actions retain a minimal nuisance value and consume scarce judicial resources.

\section{CONCLUSION}

Whether called a "private attorney general" or a "bounty hunter," the plaintiff's attorney in class and derivative actions has long been a controversial figure. Claims that such actions disproportionately result in extortionate or collusive settlements are not new, but an understanding of why such outcomes may occur requires that we move beyond character assassination and identify those legal rules that permit the parties to settle on a basis unrelated to an action's litigation odds. Here, the cost differential thesis, portfolio theory, and the claim that the lodestar formula invites structural collusion all have some explanatory power, with the last explanation seeming much the most powerful.

More generally, this Article has argued that good intentions often make bad law. An attraction of the lodestar formula is that it treats plaintiff's attorneys just like other lawyers by compensating them based on their time expended at their normal billing rates. Although this approach succeeds in disguising the fact that the plaintiff's attorney is different from other attorneys (because high agency costs make plaintiff's attorneys independent entrepreneurs), it simultaneously exacerbates the problem of collusion. Ironically, the cost of a purely fiduciary perspective, then, is to make matters significantly worse.

Beyond the specific problems associated with plaintiff's attorneys, a new critique of litigation is emerging which suggests that private enforcement imposes an externality upon society because of an allegedly excessive incentive to litigate. Although it is undeniably true that the parties to an action do not bear its full cost, this thesis fails to provide a coherent rationale that justifies attempts to repeal treble damages, reduce fee awards, or shift costs against the plaintiff's attorney. Class and derivative litigation seems the least likely context in which the private incentive to litigate will exceed the social incentive, because the stakes in such actions are asymmetric - that is, defendants expect greater benefits from the action than do plaintiff's attorneys. To say this is not to deny that there is a federal caseload crisis, that the costs of litigation are partially subsidized by the state, or that an incentive may sometimes exist to bring "frivolous" actions. Yet attempts to gauge whether the incentive to sue is excessive, inadequate, or optimal must consider much more than the mere fact that the parties do not bear all the costs of litigation.

What reforms make sense, then? If one wishes to economize on the judicial time that is today invested in monitoring class and derivative litigation, the highest priority should be given to those reforms that restrict collusion and are essentially self-policing. The percentage of the recovery fee award formula is such a "deregnlatory" reform because it relies on incentives rather than costly monitoring. Ultimately, 
this "deregulatory" approach is the only alternative to converting the courts into the equivalent of public utility commissions that oversee the plaintiff's attorney and elaborately fix the attorney's "fair" return.

There are, however, no easy victories. If the law seeks to restrict collusive settlements by moving in the direction of a percentage of the recovery fee formula, then a corollary is that the law will tend to encourage premature settlements. ${ }^{146}$ To compensate for such underfunding, the law could make greater use of multiple damage formulas, or award substantially higher fees or prejudgment interest on such fees. Move to the point, courts could employ a marginally increasing percentage of the recovery fee formula; as a benchmark, courts should determine the level of fees sophisticated individual plaintiffs pay their attorneys in the most comparable field of litigation, and then the fee should be adjusted upward to compensate the attorney for incurring the additional risk of representing the class on a contingent fee basis. These options, if politically feasible at all, would surely extend the life and increase the cost of the typical litigation, and could potentially result in overdeterrence. These tradeoffs can be debated across a variety of specific contexts, but such a debate should focus on what is truly relevant. For too long, the dominant themes in the debate over private enforcement have involved the integrity of plaintiff's attorneys and the alleged excessiveness of their fees. ${ }^{147}$ Such digressions miss the key point that it is the current structure of the law that encourages collusion and invites low level extortion.

More Draconian responses than those here proposed-such as dual fee shifting, more substantial security for expense bonds, or the further legitimization of the special litigation committee-now are visible on the horizon. These "reforms" will predictably chill an incentive for private litigation that may already be seriously suboptimal. In particular, most forms of fee shifting, including that intimated by Marek $v$. Chesny, ${ }^{148}$ are inherently more threatening to the plaintiff's side than to the defendant's in class and derivative actions because the litigation stakes are asymmetric. ${ }^{149}$ In such a context, fee shifting reverses the

146. See supra notes 55-58 and accompanying text.

147. See Miller, Of Frankenstein Monsters and Shining Knights: Myth, Reality, and the "Class Action Problem," 92 Harv. L. Rev. 664, 667 (1979) (noting "widely held" belief that bulk of money received in settlement is devoured by "avaricious attorneys"). The claim that attorneys allegedly devour the settlement fund sounds more like a description of the consequences of collusive settlements.

148. 105 S. Ct. 3012 (1985). For a discussion of this case, see supra notes 11-14 and accompanying text.

149. The plaintiff's attorney has less at stake than the defendants. See supra notes 49-54 and accompanying text. Thus, the plaintiff's attorney will be even less motivated to invest time or money in the action than the defendant because the expected loss from adverse fee shifting is larger in proportion to the plaintiff's attorney's expected payoff from the action and can exceed that payoff even when there is a probability of a plaintiff's verdict. 
litigation cost differential that typically favors the plaintiff, thus further chilling the party with the lesser incentive to litigate. ${ }^{150}$ If early settlements are to be encouraged in order to reduce the public costs of litigation, then other, less drastic means than fee shifting, including the percentage of the recovery formula, should be employed. ${ }^{151}$

Private enforcement of law has its inevitable flaws, which are largely rooted in the principal-agent problems that attend class and derivative litigation. These problems are only aggravated so long as we repress the fact that the plaintiff's attorney is different from other attorneys, both in terms of the extent of the conflict and the potential for opportunism. Once this is recognized, the basic goal of reform should be to reduce the agency costs incident to this attorney-client relationship. While various means to this end are possible-including multiple damages, more realistic fee award standards that attempt to mimic what private bargaining would have produced had it been feasible, and the use of an increasing percentage of the recovery formula-all should be understood as responses to this agency cost problem and debated in that light. At times, these responses may produce overdeterrence, but in such cases the appropriate answer is then to revise the substantive legal standard, not to create more constraining procedural rules. ${ }^{152}$ Because it applies across the board, the law of procedure can only accomplish limited objectives and cannot respond surgically to specific problems in a narrow range of litigation. When we instead attempt to revise procedure to chill "excessive" litigation, the result is likely to be to transfer wealth between plaintiffs and defendants.

This view of private enforcement as less flawed than frustrated requires some explanation of how things got this way. The cynic might argue that frustration seldom occurs by accident and that powerful social forces have quietly combined to undercut the private attorney general concept. Perhaps, there is some trnth to this claim, but a more balanced, fuller account probably should begin with how we think about law and lawyers. Even the most practical litigator or judge is

150. See supra note 138 .

151. A simpler and less chilling alternative to fee shifting against the plaintiff would be to deny the plaintiff's attorney a fee award for time expended after a settlement offer was declined when that offer was not improved upon at trial. This solution is the actual holding in Marek v. Chesney, 105 S. Ct. 3012 (1985), although the logic of Rule 68 as expounded by Marek would seem to dictate fee shifting as well. Even apart from the Rule 68 context, this alternative of fee denial can be justified based on language in Hensley v. Eckerhart, 461 U.S. 424 (1983), which emphasized that the attorney's fee must be based primarily on the "results obtained." Id. at 434 . Because time expended after a declined settlement offer obtains no additional "results" (when the trial outcome did not improve on the offer), Hensley arguably should preclude an award of attorney's fees that covers such time.

152. For example, if it is believed that Rule 10b-5 tends to encourage frivolous actions, the better answer is to revise the substantive law by imposing a scienter requirement (as the Supreme Court did in Ernst \& Ernst v. Hochfelder, 425 U.S. 185, 194-214 (1976)), not to reduce fee awards for all class actions grounded on Rule 10b-5. 
often the slave of some defunct law professor who taught him to think of the lawyer as a fiduciary. Convenient and comforting as it is to view the attorney only through this nostalgic lens of fiduciary analysis, a fixation on this mode of analysis is likely to blind us to the real issues relating to the incentives and misincentives that the law today creates for the plaintiff's attorney. Sadly, to call a lawyer a fiduciary is too often to end the analysis, not begin it. 